\title{
Compensation in the Financial Sector: Are all Bankers Superstars?
}

\author{
Claire Célérier *
}

\begin{abstract}
Based on a compensation survey among French graduate engineers, I show that a higher talent sensitivity may account for rents in the financial sector. I develop a model in which firms compete for industry-specific talent. Talent is either revealed or acquired on the job, is scalable and can be transferred across firms within the sector. As once revealed it becomes public information and workers cannot commit to long-term wage contracts, the latter capture all the benefits of the talent discovery process. The higher talent sensitivity, the higher variability in wages and career steepness. Risk aversion restricts worker ability to pay while entering the industry, which leads to excessive rents and inefficiencies in the talent discovery process. This model predicts empirical implications concerning the wage distribution, career dynamics, size of the stakes, and the use of variable compensation that fit the financial sector particularly well. First, the distribution of wages is highly convex and right-skewed. Second, higher returns to experience in the first years account for a large part of the premium. In line with a talent discovery process, career steepness is also observed. Third, wages are highly correlated with project size relative to the rest of the economy. Fourth, a time series analysis shows that the increase in the premium since the 1980s has been coupled with an increase in the size of the stakes and wage variability. Finally, the use of variable compensation appears consistent with talent retention motives.
\end{abstract}

Keywords: Finance, compensation, wage distribution, wage structure, incentives, superstars

JEL codes: G2, G24, J3, J31, M5

*Banque de France, DGEI-DMS-SAMIC - Toulouse School of Economics. Email: claire.celerier@gmail.com. 


\section{Introduction}

Since the beginning of the financial crisis, compensation in the financial sector has been at the center of the public debate. It has made politicians react, and Barack Obama, on February 4, 2009, is only one example: "For top executives to award themselves these kinds of compensation packages in the midst of this economic crisis is not only bad taste, it's bad strategy, and I will not tolerate it as President". It was even on top of the agenda of the first international meetings on the regulation of the financial sector ( $\mathrm{G} 20$ London summit, 2 April 2009). However, so far global coordination is limited and governments are concerned by the "first mover disadvantage": varying rules on pay raise risks of regulatory arbitrage and banks migration across countries. But the initial question remains: why is compensation in the financial sector so high? To answer the question I use a data set of graduates from French engineer schools. Based on a competitive model for industry specific human capital, I show that higher returns to talent may account for rents in the financial sector.

I develop a model in which firm competition for industry-specific talent leads to industry rents. Usually, in standard superstar models (Rosen, 1981), talent is considered as innate and scarcity leads to rents. In this model, innate talent is not required. Indeed, talent is industry-specific and is acquired or revealed over the career. It consists in any specific assets workers can bring with them while moving to another firm within the industry. It can range from technical knowledge to address books and fame. Scarcity arises because only incumbent workers have acquired or revealed this industry-specific talent.

There is ample evidence that firms compete for industry specific talent in the financial industry. Kostovetsky (2009) shows that the development of the hedge fund industry has led to an increase in the turnover of managers in the mutual fund industries due to lower wages. Clarke et al. (2007) examine what happens when "all stars" analysts move from one investment bank to another. They find that the new investment bank does attract a significantly larger industry market share of capital raising and M\&A deals after the arrival of the all-star, relative to the bank the analyst leaves. Godechot (2008) describes an "Hold-up" mechanism in which employees in the financial sector can threat firms to resign and hence renegociate wages. Finally, practitioners also admit that talent retention is a challenge in the financial industry. Retention issues would have been one of the hedge funds' motivations for going public: "We believed having tradable equity would provide a valuation mechanism that will help us succeed in the intense competition for talented investment professionals." (Frank, Oaktree Capital Management, 2007).

When talent is both specific to an industry but general within the industry, can only be revealed on the job, and once revealed becomes public information, then in a competitive labor market workers capture all the benefits from the talent discovery process. However, firms could use two types of contract protection to limit rents: by making individuals either to pay for the job at the beginning of their career, or to commit to long-term wage contracts. However, I show that risk aversion restricts employee ability to pay for their job. Moreover, I assume that long-term wage contracts are not enforceable as workers cannot be forced to stay in the same firm, as this would be in conflict with freedom to work.

When the worker ability to pay at entering the industry is restricted, inefficiencies in the talent discovery process arise (Terviö (2009b)). The mechanism is the following. 
Before entering the industry, workers have the same expected talent. After working one period in the industry, talent is revealed and heterogeneous. Firms compete for it and workers are offered wages depending on their observed talent. They decide to stay in the industry if the wage offer is above the outside option. The marginal worker, whose talent is higher than the population mean, is offered exactly the outside option. When a social planner sets the talent of the marginal worker that maximizes production, it faces a trade-off between the profit loss of firing a worker of talent above the population mean and the potential upside of a junior worker. However, as long term wage contracts cannot be implemented, firms do not integrate the upside potential of a junior worker in the trade-off. As a result, for production to be maximized workers must pay exactly their upside potential at entering the industry. With a restricted ability to pay, inefficiencies arise: the talent of the marginal worker is below the productive efficient threshold.

A higher talent sensitivity of the production function has two opposite effects on the talent discovery process. On the one hand, it increases superstar effects: career steepness and wage variability increase. As a result, as workers are risk averse, they will pay a lower fraction of their upside potential, which worsen the talent discovery process. On the other hand, the impact of a decrease in the talent of the marginal worker increases. As wages are set through a competitive assignment model, they increase with the worker productivity surplus relative to the marginal worker. When the productivity of the marginal worker decreases, the next best worker can negotiate a fixed wage surplus that spills upwards along the distribution of talents. This wage surplus increases with talent sensitivity. This allows workers to capture a higher fraction of future rents and thus to pay a higher fraction of their upside potential. I show that the average talent in the industry is concave in industry talent sensitivity.

The model also describes the impact of changes in talent sensitivity when firms can enter the industry and face heterogeneous costs of capital. When talent sensitivity increases, new firms with a higher cost of capital enter the industry. This has two opposite effect on senior rents. On the one hand, senior rents depend on the productivity of the marginal worker. As the latter will be assigned to a smaller firm, this increases superstar effects. On the other hand, new firms are smaller and have consequently a lower cost at discovering talent. This has an upward impact on industry turnover and the average talent within the industry.

Using a 1983-2010 survey among French graduate engineers, I test the empirical predictions of the model. This survey gathers several unique specificities. First, due to the size of the sample, it provides unique data on the French educational elite. Indeed, each survey comprises on average 30,800 individuals, standing for nearly $6 \%$ of the total population of French graduate engineers. Moreover, it covers 27 years, from 1983 to 2010. Second, information concerning careers and compensation is very detailed. There is information on the amount and structure of compensation, current job and career history, and personal data. Finally, the 2010 survey provides unique information on size at stakes.

The first set of empirical implications of my model concerns the wage distribution: the higher industry talent sensitivity, the higher the industry premium and variance in wages. I first show that there exists a premium for working in the financial sector. More precisely, controlling for a large set of individual characteristics, I find that this premium has increased from 1983 onwards and amounts to 33\% on average from 2005 to 2007. From 1998 on, the financial sector is the sector in which French engineers are better 
paid. Second, based on a standard equation with industry dummies, I find that the distribution of wages is more right-skewed than in other sectors. This is confirmed by a quantile regression: the premium in the financial sector is higher in the top quantiles of the wage distribution. Finally, the increase of the premium over years has been combined with an increasing share of the financial sector in the top $1 \%$ of the wage distribution.

The second set of empirical predictions relates wage evolution and experience. As talent is revealed on the job, both returns to experience, career steepness and career persistence are high when talent sensitivity is high. This is consistent with the estimation of a standard wage equation across subsamples ranked by years of experience within the financial sector. The premium and the variance in wages increase over years of experience. Second, Oyer (2008) finds that there is a strong persistence in investment banking careers. He shows that the probability that a Stanford MBA graduates who starts a career in investment banking will work there later is about 73 percentage points higher than someone who starts elsewhere.

Third, the model relates compensation with the size of projects workers are assigned to: when firm profits are sensitive to workers' talent, the best talented workers are naturally assigned to the largest projects. In the 2010 survey, interviewees are asked the amount of capital they manage and the profit they are responsible for. I show that within the financial sector, size at stakes accounts for one third of the variance in wages. Second, in a cross industry analysis, I find that wages depend on both size at stakes and the average market capitalization per employee in the US corresponding industry. The most striking result is the following: when I allow talent sensitivity to vary across industry, not only is it higher in the financial sector but also it makes the financial sector premium disappear.

My model shows that increases in the financial sector premium, firm profits and variability in wages should be correlated. Based on US data for the financial industry, I find that the market size per employee in the financial sector has increased in line with the premium. Second, three quantile regressions over three different periods of the sample show that variability in wages has increased. I also find an increase in profits. Finally, the financial sector premium may be explained by a higher share of deregulated finance, which I mesure computing the fraction of off-balance sheet activity over total assets.

Finally, the last set of empirical implications of my model is about the structure of compensation. I show that if there exist industry-wide stochastic changes in sensitivity to talent and if renegotiating fixed wage is costly, then it is optimal to index compensation on profits. I find first that the increase in the premium in the financial sector is correlated with the share of variable compensation. Second, the latter is correlated with profits, which is contrary to the assumption that variable compensation should vary independently of general market conditions (Holmström (1982)).

My paper makes three main contributions. First it provides new stylized facts on compensation in the financial sector. The literature has explored several aspects of compensation in the financial sector. A first one is the level of compensation relatively to the rest of the economy. Philippon and Reshef (2009) use data of the Census Population Survey (CPS) to compute the premium from working in the financial sector. Based on a Stanford MBAs survey, Oyer (2008) compares MBA graduate compensation over the career in the financial sector to other sectors. Finally, Goldin and Katz (2008) use data 2005 earnings from a survey among Harvard alumni. All of them find that there is a 
premium for working in the financial sector, from 40\% in Philippon and Reshef (2009) up to more than 100\% in Oyer (2008) and Goldin and Katz (2008). The second aspect is the increase of relative compensation since the early 1980s. Philippon and Reshef (2009) describe how, since the 1980s, financial sector's compensation has increased compared to the rest of the private sector. Kaplan and Rauh (2009) for US, Bell and Van Reenen (2010) for UK and Godechot (2011) for France find that the share of the financial sector in top end brackets of the income distribution has significantly increased.

Second, few papers in the literature test empirically an explicit model accounting for the premium in the financial sector. Philippon and Reshef (2009) find that financial deregulation and corporate activities linked to IPO and credit risk increased the demand for high skilled-paid employees. However, they consider that it cannot account for a large excess wage at equilibrium in a world with perfect mobility across jobs. Therefore, they take into account earning profiles and show that under realistic assumptions on discounting and risk aversion steeper and riskier lifetime wages can explain more than half of the premium. Oyer (2008) shows that the premium cannot be due to unobserved innate talent. His results suggest that it is rather due to a compensating differential for working conditions and/or finance specific skills. Kaplan and Rauh (2009) consider that scale effects combined with a skill biased technological change may account for the change in the composition and variance in the top end brackets of the wage distribution.

Third it contributes to the understanding of the labor market in an industry in which firms compete for industry-specific talent when workers are risk averse. Terviö (2009b) shows that under the realistic assumptions of limited liability and limited commitment ability, inefficiencies in the talent discovery process arise. This model differs with Terviö (2009b) in the following points. First, the limited liability of worker is endogenous and due to risk aversion. Second, the size of capital in the production function is endogenous and set to maximize firm profits, whereas the demand function and prices are considered as exogenous. Third, industries differ in sensitivity to talent, which leads to new results in term of industry wage differentials. The model also analyzes the opposite effects of a higher talent sensitivity on the talent discovery process and the dynamics of the industry when senstivity to talent varies and firms differ in productivity due to heterogeneous cost of capital.

The paper proceeds as follows. In the following section I develop a competitive model for industry specific talent. The third section describes the data used and provide stylized facts on compensation in the financial sector. The fourth section tests the empirical implications on respectively the wage distribution, career dynamics, size at stakes, time evolution, and the use of variable compensation. Finally, the eighth section concludes.

\section{A Model of Industry-specific Talent and Rents}

The purpose of my model is to analyse the impact of talent sensitivity on the labor market in an industry in which firms produce an economic surplus combining a worker ability and adjustable capital when the worker ability is industry specific, can be transferred across firms within the sector and is publicly revealed on the job. This model describes how workers risk aversion and discounting lead to excessive lifetime rents and ineffiencies in the talent discovery process. I also show how a labor market react to changes in industry 
sensitivity to talent when the number of firms is fixed. The predictions of my model will then guide my empirical analysis of compensation in the financial sector.

\subsection{Assumptions}

\subsubsection{Production}

Consider an industry in which firms produce an economic surplus combining adjustable capital $y$ and a worker's talent $s$. In particular, the surplus generated by a worker of talent $s$ is:

$$
g(s, c)=s \times c \times y^{\alpha}-r y
$$

with $\alpha<1, r<1$ and $c>0 . c$ and $s$ are exogenous: $c$ quantifies the industry sensitivity to talent and $s$ the worker ability. $y$ is endogeneous. $c$ is the key variable of the model.

Firms are risk neutral and does not discount future earnings. The number of firms in the considered industry is sufficiently large so that there is no uncertainty about the distribution of talent. Moreover, it is fixed and equal to the industry workforce (there is no free entry of firms).

\subsubsection{Careers}

There is an infinity of workers facing an outside wage $w_{0}$ living for $T+1$ periods. When starting a career in this industry, workers are considered as junior and have the same expected talent $\bar{s}$. But after having worked one period, talent is revealed and is publicly observable. It is drawn from a cumulative distribution function $F$ with positive support $\left[s_{\min } ; s_{\max }\right] . s$ is specific to the industry but general within the industry: as a result a worker can transfer his talent in any firms of the same industry.

A worker's career in the considered industry unfolds as follows. In the first period, the worker starts working as a junior. His talent is $\bar{s}$ and he receives a wage $w_{1} \cdot w_{1}$ is the starting wage of the junior worker. While working as a junior, the worker acquires industry-specific talent $s$, or $s$ is revealed. Then, after the first period of his career, he is considered as a senior and $s$ is publicly observable. As $s$ can be transferred across firms within the industry, firms compete over $s$. Let $w(s)$ be the wage offer for a senior worker with industry specific talent $s$. The senior worker can either decide to stay in the industry for $T$ more periods and earn $w(s)$ (if $w(s) \geq w_{0}$ ) or to exit the industry definitely and earn an outside wage $w_{0}$ (if $w(s)<w_{0}$ ). This will depend on his talent $s$. I denote by $\phi$ the talent threshold above which the worker stays in the industry. The proceed of a worker's career is described in Figure 1. 


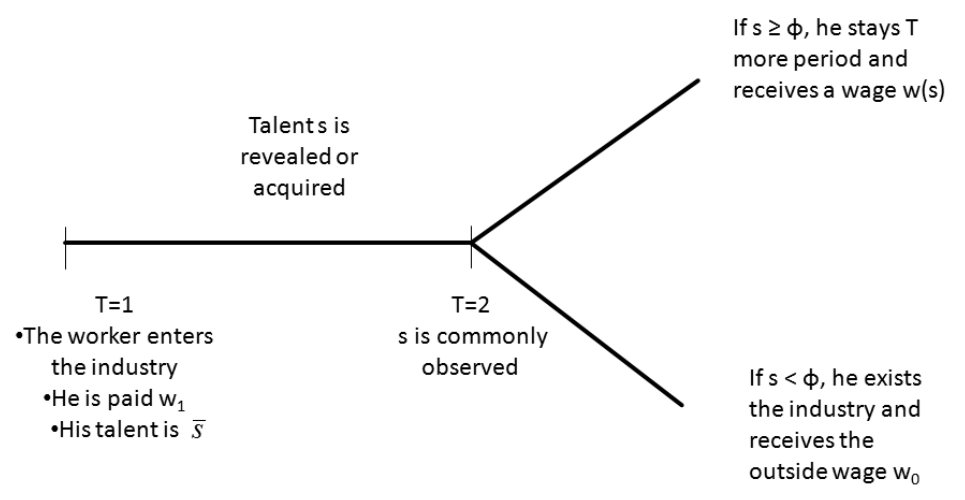

Figure 1

Career development

Talent sensitivity $c$ impacts careers through, first, senior wages, second, the exit threshold. Workers are risk averse and discount their future utility.

\subsubsection{Market Imperfections}

I consider two market imperfections. First, long term wage contracts are not enforceable because workers cannot commit to decline higher offers from other firms in the future. This implies informational inefficiencies in the talent discovery process. Indeed, there is a cost for the firm at discovering talent through the hiring of a junior worker. However, as once revealed talent is publicly observable, the benefits from the talent discovery process cannnot be captured by the firm. If workers cannot compensate the firm for this cost, the level of talent is lower than at the maximum level of production. This leads to the second market imperfection: as workers are risk averse, if they cannot perfectly hedge against the realization of their own talent, this restricts the worker willingness to pay for entering the industry in period 1 . The certainty equivalent of future earnings is lower than the value of these future earnings.

\subsection{Job Market Equilibrium Conditions}

\subsubsection{Adjustable Capital}

Firms maximize the surplus function $g(s, c)$. As a result, the optimal level of adjustable capital $y^{*}(s, c)$ assigned to a worker of talent $s$ is:

$$
y^{\star}(s, c)=\arg \max _{y}\left\{s c y^{\alpha}-r y\right\}=\left(\frac{\alpha s c}{r}\right)^{\frac{1}{1-\alpha}}
$$

Whereas the size of adjustable capital is the same across junior workers within the industry (with $s=\bar{s}$ ), it varies across senior workers. For a given distribution of talent, I observe first that the size of adjustable capital per senior worker is increasing with talent sensitivity $c$. Second, in line with standard models of superstars, it is increasing and convex in talent $s$. Moreover, as $\frac{\delta^{2} y^{\star}}{\delta s^{2}}=\left(\frac{\alpha c}{r}\right)^{\frac{1}{1-\alpha}} \frac{\alpha}{s(1-\alpha)^{2}}$, convexity increases with talent sensitivity. 
Lemma 1 The amount of adjustable capital y managed per senior worker increases and is convex in talent s. The higher talent sensitivity $c$, the higher the convexity, the variance and the mean of the distribution of adjustable capital per worker.

The output of a senior worker of talent $s$ is:

$$
g(s, c)=r \frac{1-\alpha}{\alpha} y(s, c)
$$

\subsubsection{Wages}

Worker wages after the first period of their career are set following two conditions. First, as firms compete over $s$, under perfect competition the marginal benefit of hiring a slightly better senior worker must be equal to its marginal cost:

$$
\begin{gathered}
w^{\prime}(s)=g^{\prime}(s) F^{\prime}(s) \\
w^{\prime}(s)=\frac{r}{\alpha}\left(\frac{\alpha c}{r}\right)^{\frac{1}{1-\alpha}} s^{\frac{\alpha}{1-\alpha}} F^{\prime}(s)
\end{gathered}
$$

Let $w(\phi)$ be the worker's wage at the exit threshold. Any staying worker's wage is:

$$
w(s \mid s \geq \phi)=\int_{\phi}^{s} \frac{r}{\alpha}\left(\frac{\alpha c}{r}\right)^{\frac{1}{1-\alpha}} u^{\frac{\alpha}{1-\alpha}} f(u) d u+w(\phi)
$$

Second, at the exit threshold, workers must be indifferent between exiting or not the industry, implying:

$$
w(\phi)=w_{0}
$$

and

$$
w(s \mid s \geq \phi)=\int_{\phi}^{s} \frac{r}{\alpha}\left(\frac{\alpha c}{r}\right)^{\frac{1}{1-\alpha}} u^{\frac{\alpha}{1-\alpha}} f(u) d u+w_{0}
$$

The wage surplus of a senior worker of talent $s$ is the sum of all the production surpluses relative to the next best worker produced by him and workers below him in the ranking of talent but above the marginal worker of talent $\phi$. In other words, senior workers earn the outside wage plus their marginal productivity, if we consider as the margin the production of the worker of talent $\phi$. When the exit threshold $\phi$ decreases, the marginal worker produces less. As the next best competitor becomes relatively more productive, she can raise her wage by a fixed amount. This price increase will spill upwards along the whole labor force in the industry, and wages increase. As a result, the lower $\phi$ the higher senior worker wages in the industry. Moreover, when $c$ increases, the impact of talent on production increases. As a result, heterogeneity and convexity in wages increase.

Lemma 2 Senior wages are increasing and convex in talent and a decreasing function of the exit threshold $\phi$. When talent sensitivity increases, convexity in wages increases. 


\subsubsection{Average Production}

Let define as $i(\phi)$ the fraction of junior workers in the industry. Vacancies left by both juniors with a level of talent lower than the exit threshold $\phi$ and veterans that retire must be equal to the number of junior entrants. As a result, $i(\phi)$ solves:

$$
\begin{gathered}
F(\phi) i(\phi)+(1-i(\phi)) \frac{1}{T}=i(\phi) \\
i(\phi)=\frac{1}{1+T(1-F(\phi))}
\end{gathered}
$$

The industry turnover decreases when the exit threshold increases.

Let define the average production in the industry as a function of $\phi, P(\phi)$. We have:

$$
P(\phi)=i(\phi) g(\bar{s})+(1-i(\phi)) E[g(s \mid s \geq \phi)]
$$

In the following section, I describe the optimal turnover as the one that maximises the average production within the industry, and the turnover with risk averse workers.

\subsection{Productive Efficiency and Industry Turnover}

\subsubsection{The Productive Efficient Exit Threshold}

First, I consider the exit threshold $\phi^{*}$ that maximizes the production surplus.

The first order condition to maximize $P(\phi)$ is:

$$
g(\phi)-g(\bar{s})=T(1-F(\phi))(E[g(s \mid s \geq \phi)]-g(\phi))
$$

When the industry switches a senior worker of talent $\phi$, with $\phi \geq \bar{s}$, to a junior worker there is an immediate cost due to the gap between the senior worker talent and the junior expected one. However, there is also a benefit from the upside potential of the junior worker when he stays in the industry. At the marginal exit threshold, the immediate cost is exactly compensated by the expected surplus. As sensitivity to talent impacts bost the upside potential of a junior and the immidiate cost, the optimal exit threshold does not depend on sensitivity to talent. Using $w(s \mid s \geq \phi)=E[g(s \mid s \geq \phi)]-g(\phi)+w_{0}$, I can write:

$$
g\left(\phi^{*}\right)-g(\bar{s})=T\left(1-F\left(\phi^{*}\right)\right)\left(E\left[w\left(s \mid s \geq \phi^{*}\right)-w_{0}\right)\right.
$$

The LHS of the equation is increasing over the interval $\left[\bar{s} ; s_{\max }\right]$ on the interval $\left[0 ; g\left(s_{\max }\right)-g(\bar{s})\right]$. The RHS is decreasing over the interval $\left[\bar{s} ; s_{\max }\right]$ on the interval $\left[0 ; T(1-F(\bar{s}))\left(w(s / s \geq \bar{s})-w_{0}\right)\right]$. As a result, $\phi^{*}$ exists, is unique and is in the interval $\left[\bar{s} ; s_{\max }\right]$.

Proposition 1 The exit threshold that maximizes production is unique, above the population mean and does not depend on industry talent sensitivity. 


\subsubsection{Risk Neutral and Unconstrained Workers}

As long term wage contracts cannot be implemented, firms will not be able to capture the upside potential of the junior worker. As a result, for production to be maximized, the worker must pay exactly this upside potential at entering the industry. Indeed, at equilibrium, firms are indifferent between a worker of type $\phi^{*}$ and any junior worker of expected talent $\bar{s}$ if and only if:

$$
g\left(\phi^{*}\right)-w_{0}=g(\bar{s})-w_{1}
$$

where $w_{1}$ is the worker's starting wage. I define $w_{1}=w_{0}-b^{*}$, in which $b^{*}$ is the exogeneous ability of the worker to "pay" for the job.

It implies:

$$
b^{*}\left(\phi^{*}\right)=T\left(1-F\left(\phi^{*}\right)\right)\left(E\left[w\left(s \mid s \geq \phi^{*}\right)\right]-w_{0}\right)
$$

When the worker can pay $b^{*}\left(\phi^{*}\right)$ at entering the industry, there is on average no life time rents in the industry. The average level of production is equal to the level of production at the exit threshold. The following figure simulates a worker earning profile in two industries with two different level of talent sensitivity $c$. It suggests that when talent sensitivity increases, the starting payment at entering the industry increases more than proportionally.

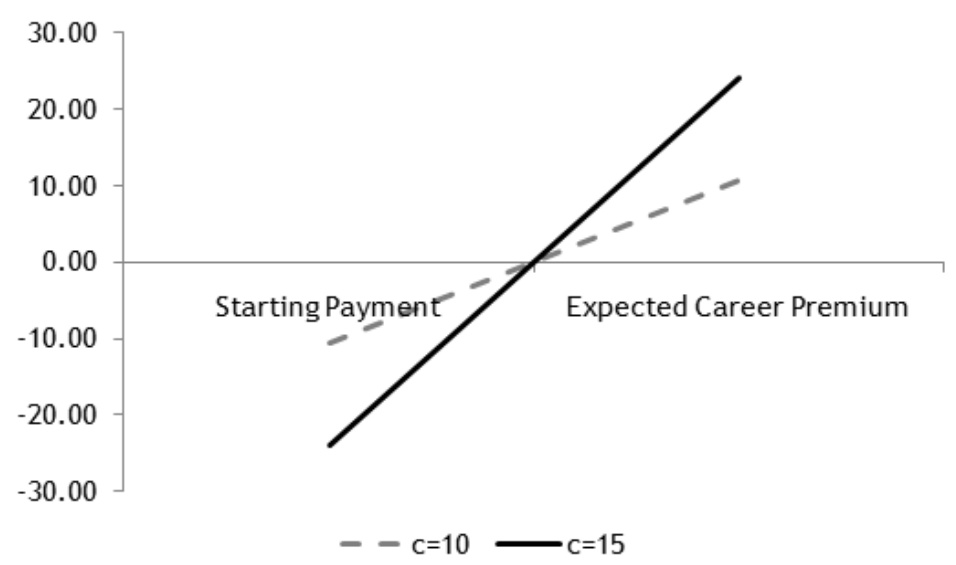

Figure 2

Wage profile across industries with different level of talent sensitivity

The graph is drawn assuming that the distribution of talent is uniform over the interval $[0 ; 1], T=15$ and talent ability to pay at entering the industry is $b^{*}$

Proposition 2 In an industry sensitive to industry specific talent when long term wage contracts cannot be implemented, there is no lifetime rents and production is maximimised if and only if workers pay their own potential upside production at entering the industry. As a result, when industry sensitivity increases starting wages decrease and career steepness increases. 
Concerning firms, as workers capture the suplus generated by their talent, they are indifferent between a worker of type $\phi^{*}$ and any worker of type $s \geq \phi^{*}$. As a result, firm revenue per worker does not depend on $s$ but depends on the exit threshold $\phi^{*}$. Let $R(c, \phi)$ be the firm revenue per worker:

$$
R\left(c, \phi^{*}\right)=g\left(\phi^{*}\right)-w_{0}
$$

When talent sensitivity increases, firm revenue increases. However the existence of industry rents does not imply that firm owners earn excess returns in the long term. Indeed, either they compensate for the capital that has been sunk at entering the industry, or a higher talent sensitivity is coupled with more risk taking. Moreover, I assume that when $c$ increases, the fixed cost for a firm at entering the industry increases also. This can be justified by the fact that $c$ increases due to a higher level of information technology, etc. As a result, I consider that the number of firms in the industry is fixed.

\subsection{Industry Turnover with Risk Averse Workers}

\subsubsection{The Constrained Exit Threshold}

I now compute the equilibrium exit threshold $\phi$ when workers have an exogeneous limited ability to pay at entering the industry $b$.

At equilibrium, at the exit threshold $\phi$, firms are indifferent between a worker of type $\phi$ and any junior worker of expected talent $\bar{s}$. As a result, $\phi$ solves:

$$
g(\phi)=g(\bar{s})+b
$$

Let consider that workers can only pay a fraction $k$ of the expected rents $b^{*}$, with $k \in[0 ; 1] . \phi$ verifies:

$$
\begin{gathered}
g(\phi)-g(\bar{s})=k b^{*} \\
g(\phi)-g(\bar{s})=k\left(g\left(\phi^{*}\right)-g(\bar{s})\right) \\
\phi=\bar{s}\left[k\left(\frac{\phi^{*}}{\bar{s}}\right)^{\frac{1}{1-\alpha}}+1-k\right]^{1-\alpha}
\end{gathered}
$$

$\phi$ is an increasing function of $k$. When $k=0$, i.e. when workers cannot pay at entering the industry, the level of talent is exactly the population mean. Firms does not explore talent and only reject workers with a talent lower than the expected one.

Proposition 3 As the ability of workers to pay for a job decreases, the exit thereshold decreases.

As senior worker rents depend on the ability of the marginal worker, when the exit threshold $\phi$ decreases, senior worker rents increase: rents due to inefficiencies in the talent discovery process emerge. Indeed, workers with a level of talent above the population mean but below the threshold $\phi^{*}$ stays in the industry. As a result, the senior wage of a worker of given talent $s$ increase because it is set comparatively with a worker of lower talent. The following figgure describes how the average wage premium of a senior worker 
increases whith talent sensitivity when the latter is financially constrained, and when he is not. It appears that the impact is higher when sensitivity to talent is higher.

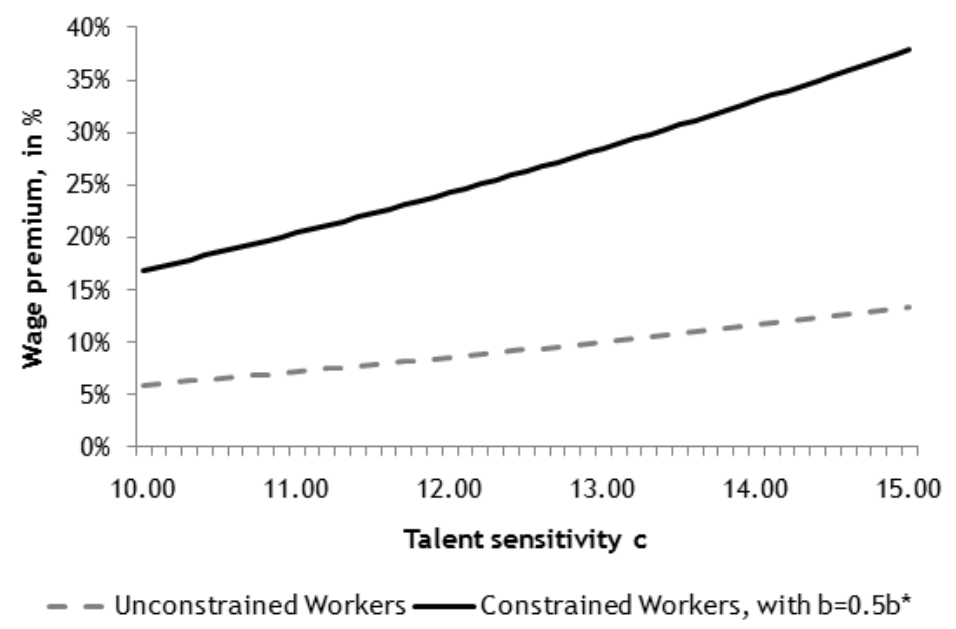

Figure 3

Average lifetime wage increase when $b=1 / 2 b^{*}$

The graph is drawn assuming that the distribution of talent is uniform over the interval $[0 ; 1], T=15$, $w_{0}=12$ and talent ability to pay at entering the industry is $b^{*}$

Proposition 4 As the ability to pay for a job decreases, the impact on career steepness and lifetime rents is higher when sensitivity to talent is higher.

Now I consider the case in which the ability of workers to pay at entering the industry is fixed over time and across industries at $b=10.71$ which corresponds in the parametrization at $b^{*}$ when $c=10$ and $\frac{1}{2} b^{*}$ when $c=15$, and $85 \%$ of the outside wage. Let assume that $c=10$ In this case workers pay the outside wage at entering the industry, which could be similar to working $30 \%$ more during three years at not talent requiring tasks for exemple. The senior worker premium is $6 \%\left(w_{0}=12\right)$. Let assume that sensitivity to talent increases up to $c=14$. In this case, $k=\frac{1}{2}$ and the senior worker premium amounts now to $34 \%$. This first simulation shows how the premium could have increase in the financial sector due to higher talent sensitivity and information inefficiencies (without information inefficiencies senior worker premium would have increased up to $12 \%$ ). The following figure illustrates the impact of an increase in talent sensitivity on the talent and wage distributions when the worker ability to pay at entering the industry is fixed. The average level of talent decreases and wage dispersion increases. In this parametrization example, firm profit per worker increases from 0 to 10. 

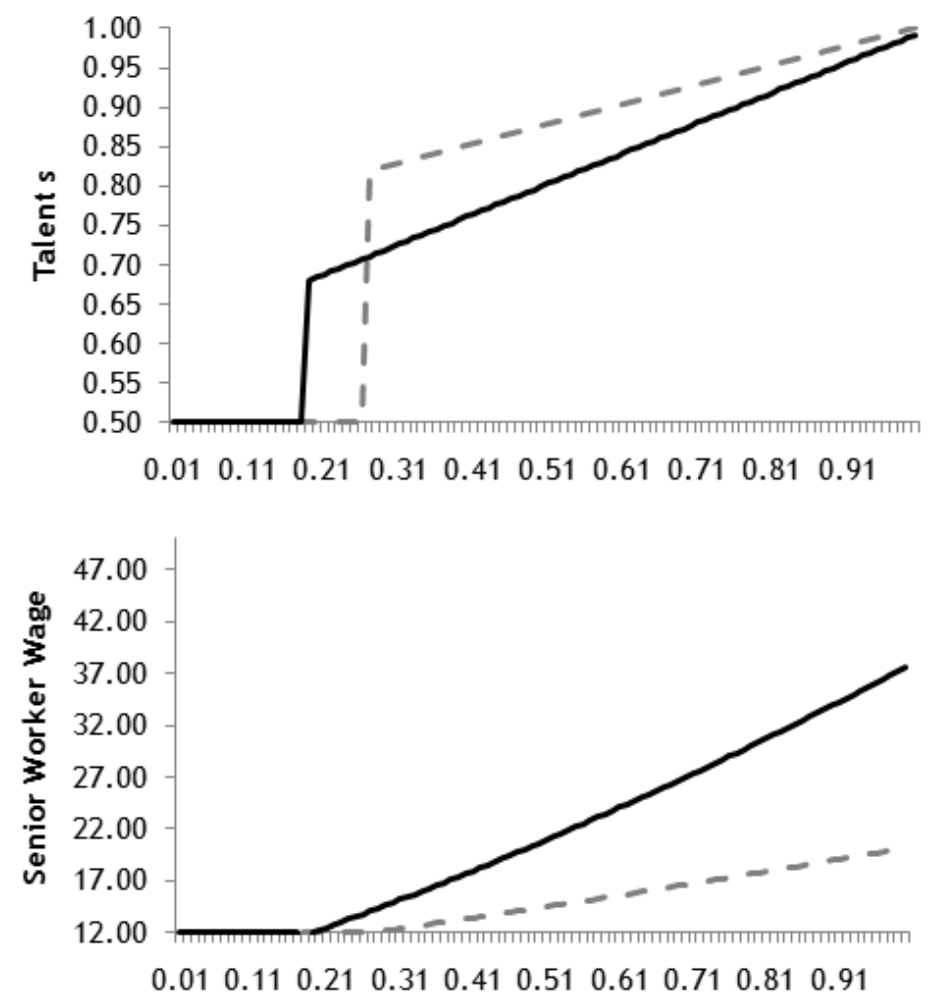

Centiles

$-c=10-c=14$

Figure 4

Wage and talent distribution evolution when talent sensitivity $c$ increases and $\mathrm{b}$ is fixed $(=10.7)$

The graph is drawn assuming that the distribution of talent is uniform over the interval $[0 ; 1], T=15$, $w_{0}=12$

\subsubsection{Starting Wages with Risk Aversion and Discounting}

Now I consider the measure of the worker ability to pay at entering the industry $k$ as endogeneous. $k$ depends on the value of the job for workers in the first period of their career. As they are risk averse and discount their future earnings, $k$ is strictly lower than 1. More precisely, $k$ solves:

$$
\begin{aligned}
& \sum_{t=1}^{T} \beta^{t}\left[\left(1-F\left(\phi_{k}\right)\right) \int_{\phi_{k}}^{1} u(w(s)) f(s \mid s \geq \phi) d s+F\left(\phi_{k}\right) u\left(w_{0}\right)\right]+u\left(w_{0}-k b^{*}\right)=\sum_{t=0}^{T} \beta^{t} u\left(w_{0}\right) \\
& u\left(w_{0}-k b^{*}\right)=\sum_{t=0}^{T} \beta^{t} u\left(w_{0}\right)-\sum_{t=1}^{T} \beta^{t}\left[\left(1-F\left(\phi_{k}\right)\right) \int_{\phi_{k}}^{1} u(w(s)) f(s \mid s \geq \phi) d s+F\left(\phi_{k}\right) u\left(w_{0}\right)\right]
\end{aligned}
$$


Where $u(c)$ is the worker utility function. Whereas the left-hand side decreases with $k$, the right-hand side increases with $k$ as soon as risk aversion is high enough or the discount factor $\beta$ is low enough. In this case, $k$ has a solution, and this solution is concave in $c$.

Proposition 5 With risk averse workers, the ability to pay at entering the industry is restricted. If risk zversion is high enough or the discount factor low enough, it is endogeneously defined, and it is a concave function of $c$. Let $\bar{\rho}$ be the risk aversion coefficient that maximises $k$ :

- If $\rho<\bar{\rho}$, when c increases, the talent discovery process is improved. The average talent in the industry increases.

- If $\rho>\bar{\rho}$, when c increases, the talent discovery process is worsen. The average talent in the industry decreases.

The following figures describe the talent and wage distribution in the parametrization case when $k$ is set endogeneously. I assume a discount factor of $\beta=0.8$ and a constant relative risk aversion function $u(c)=\frac{c^{1-\rho}}{1-\rho}$, with $\rho=\frac{1}{2}$. I assume that at $t=0$ the utility function is linear, so that the wage can be negative in the first period. I estimate that $k=0.55$ when $c=10$ and $k=0.70$ when $c=14$. The exit threshold is lower than the optimum in both cases. However, it is higher when sensitivity to talent is higher. This is due to the higher impact of a marginal decrease of the exit threshold on expected rents, which is not compensated by a higher discount due to the higher dispersion in wages. 

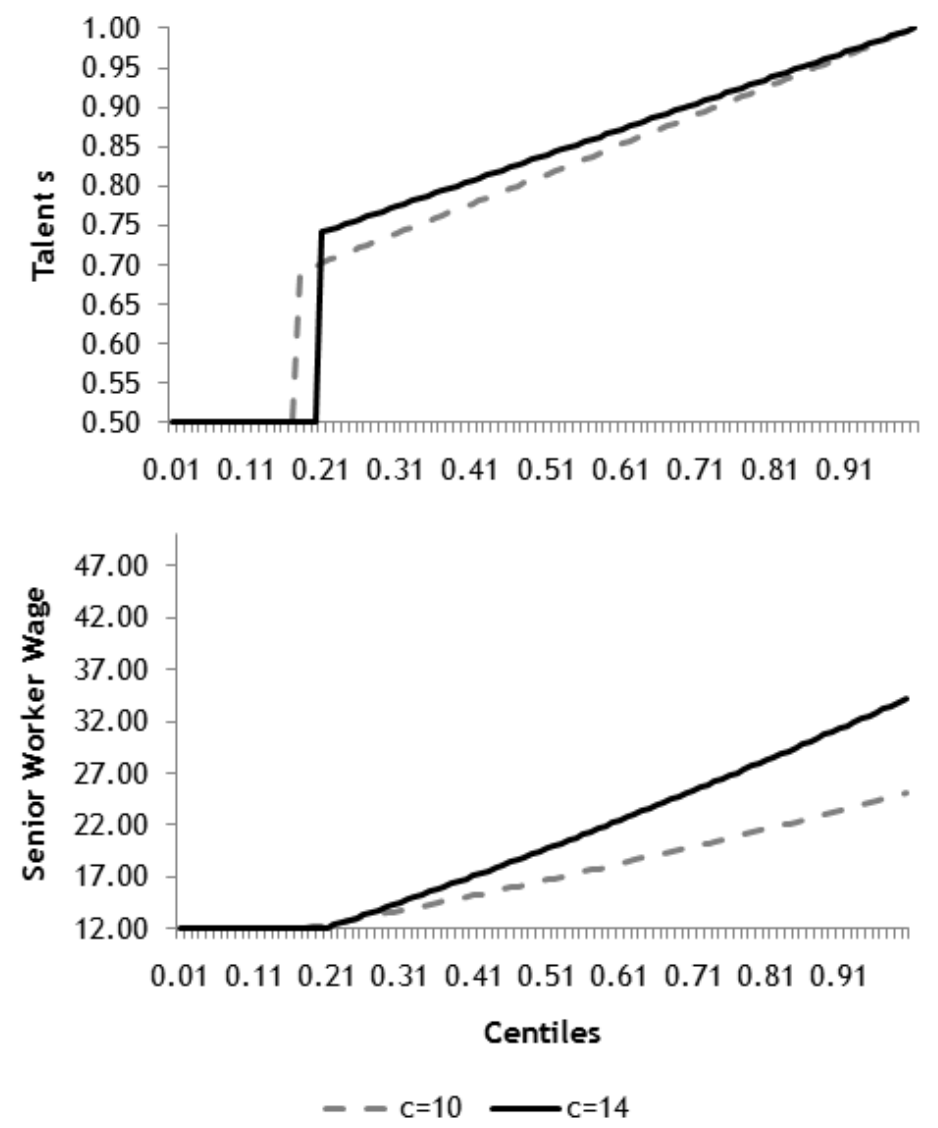

Figure 5

Wage and talent distribution evolution when talent sensitivity $c$ increases and $\mathrm{b}$ is endogeneous

The graph is drawn assuming that the distribution of talent is uniform over the interval $[0 ; 1], T=15$, $w_{0}=12, u(c)=\frac{c^{1-\rho}}{1-\rho}$ and $\beta=0.8$

To conclude, when sensitivity to talent increases, this can lead to both a higher dispersion in wages and higher rents and an improved talent discovery process.

\subsection{Dynamics in Talent Sensitivity}

I now consider what are the consequences of changes in talent sensitivity $c$. Firms have different cost of capital $r$, indexed by their type $\theta$. Firms profit is then:

$$
\pi(\theta, s, c)=\operatorname{scy}(s, c)^{\alpha}-r(\theta) y(s, c)-w_{0}
$$

As workers capture all the benefit of a talent higher than the exit threshold, firms profit is also:

$$
\pi(\theta, s, c)=\phi c y(s, c)^{\alpha}-r(\theta) y(s, c)-w_{0}
$$

Productivity levels are drawn from a distribution function $\mu(\theta)$ over the interval 
$(0 ; \inf \infty)$. A new firm enter the industry as soon as:

$$
\pi(\theta, \phi, c) \geq 0
$$

When heterogeneity in productivity is cumulated to heterogeneity in talent, superstar effects incease. As a result, when sensitivity to talent increases, firms with a lower $r$ enter the industry.

Proposition 6 When talent sensitivity increases the size of the sector increases. Indeed, firms with a lower productivity $r$ enters the industry There is two opposite effects on the variability in wages:

- An upward effect, due to a higher heterogenity in firms and a higher marginal productivity in talent

- A downward effect, due to a higher turnover, as firms wit a higher $r$ have lower costs at discovering talent

The talent discovery process may be improved depending on the impact of a change in $c$ on the entry of firms. If the fraction of firms entering the market is high enough, the talent discovery process and turnover will improve.

\subsection{Uncertainty and Variable Compensation}

Now I consider the use of a performance-based compensation contracts. Whereas such contracts are often considered as "incentive" contracts here they are used to keep wages in line with the outside option.

There are two states of nature $\lambda_{t}, \lambda_{t} \in\left\{\lambda_{l}, \lambda_{h}\right\}$. Industry talent sensitivity $c_{t}$ varies over the states of nature. $c_{t}=c_{h}$ if $\lambda_{t}=\lambda_{h}$ and $c_{t}=c_{l}$ if $\lambda_{t}=\lambda_{l}$, with $c_{h}>0$ and $c_{l}>0$. $\lambda_{t}$ and $c_{t}$ are publicly observed before profits are realised. The model unfolds as follows:

1. The worker sarts his career and receives a wage $w_{1}$

2. His talent $s$ is revealed. If $s>\phi$ he stays in the industry

3. Firms and workers observe the expected state of the economy in period $2, \lambda_{2}$. The worker receives a wage offer $w(s)$ composed of a fixed payment $f(s)$, and a variable share $v\left(s, \lambda_{t}\right)$ depending on the state of nature in period $t$.

4. Profits are realised, the worker receives his pay composed by $f(s)$ and $v\left(s, \lambda_{2}\right)$

5. Firms and workers observe the expected state of the economy in period $3, \lambda_{3}$. If necessary, the firm adjust the terms of the contract inducing a cost $k>0$ and the worker stays in the firm

6. Profits are realised and the worker receives his pay composed by $f(s)$ and $v\left(s, \lambda_{3}\right)$ 
The same process is repeated until the end of the worker's career.

As there is a cost $k$ at negotiating wages when the expected state of the economy is observed, it is optimal for the firm to offer the following contract:

$$
f(s)=w\left(s, c_{l}\right)
$$

and $v\left(s, \lambda_{t}\right)=w\left(s, c_{h}\right)-w\left(s, c_{l}\right)$ if $\lambda=\lambda_{h}$, or 0 if $\lambda=\lambda_{l}$ As a result, variable compensation increases in line with industry talent sensitivity. It implies that the variable share in wages is correlated first across workers within the industry second with industry rents per worker.

Proposition 7 Variable compensation increases in line with revenue per worker in the industry and is correlated between workers within the industry.

\subsection{Empirical Implications}

My first set of empirical predictions relates industry rents to wage distribution characteristics. Indeed, when sensitivity to talent increases, both industry rents and wage skewness increase. This is an implication of Lemma 2. I name "superstar industrye" an industry in which sensitivity to talent is relatively high.

Wage Distribution Prediction There is a premium in the superstar industry. This premium is due to first, the higher productivity of workers, second, dysfunctions in the talent discovery process. The variance in wages is higher and the distribution is skewed to the right.

The second set of empirical predictions concerns the wage evolution over experience.

Career Dynamics Prediction The premium in the superstar industry increases as talent is revealed, as well as the variance in wages. Indeed, the model predicts that at the first period of the economy workers are ex-ante identical and receive the same wage $w_{1}$ whereas when $s$ is revealed they are heterogeneous in talent and receive $w_{s}$, with $w(s)>w_{1}$ and $w_{s}$ convex in $s$. This one-shot learning process is a key simplification to keep the model tractable. However, Terviö (2009) shows that results are analogous in a setup in which information about talent is revealed gradually over time. This implies higher returns to experience in the superstar industry than in the rest of the economy.

Careers in the superstar industry should be persistent meaning that the superstar industry does not recruit from other sectors. Indeed, when industry sensitivity to talent increases and the ability to pay at entering the industry is constant across industries, then the exit threshold decreases. As a result, the industry turn over is lower in the superstar industry than in others. This result is in line with Oyer (2009).

My model relates wage distribution characteristics with size effects.

Size Prediction The amount of adjustable capital cannot be observed due to industry fixed effects. However, sensitivity to capital under management is higher in the superstar industry. The premium in the superstar industry can be explained by the interaction of 
a firm fixed effect and capital under management, and the main effect of capital under management.

Wages in the superstar industry, profits and market size per employee increase in line with sensitivity to talent.

Variable compensation prediction The share of variable compensation is higher in the superstar industry and increases over time with wages and profit per worker.

\section{Data}

\subsection{Data Description}

The data ${ }^{1}$ are based on a mailed survey among French graduate engineers lead by the French Engineer and Scientist Council $\left(\mathrm{IESF}^{2}\right.$ - Conseil National des Ingénieurs et des Scientifiques de France). The IESF is a federation of 160 alumni organizations of French engineer schools. The process of the survey is the following. The IESF designs the survey and each participating alumni organization sends it to engineers they have personal information on. Finally, the IESF merges the data. The survey has been conducted every five years from 1983 to 1998, every two years from 1998 to 2004 and then every year from 2004 onwards. Until 2000 the survey is postal, in 2002 the survey is both postal and e-mailed and from 2004 on, the survey is only e-mailed. As respondents are not identified over time, these are cross sectional data. Partly due to the use of the internet, the size of the sample increases over time and amounts to more than 40,000 respondents from 2007 onwards. As at the end of 2008, the number of French graduated engineers of less than 65 years is estimated at around 681,400 (IESF, 2008), the sample stands for nearly $6 \%$ of the total population of French engineers. More precisely, this sampling rate varies over the period from $4 \%$ up to $7 \%$. Table 1 provides summary statistics.

The survey has many unique specificities. First, due to the size of the sample it provides unique data on French workers with a high level of education. ${ }^{3}$ Second, it includes French engineers working abroad. They represent $9.4 \%$ of the total sample, $15 \%$ of the sample of engineers working in finance. Third, it gathers a great range of variables that can be classified into six groups: personal data, job description, compensation level and structure, firm description, satisfaction, job history. Interviewees also provide the industry official classification code indicated on their pay sheet, the five digit NAF code, which is equivalent to the US four digit SIC code. See Annex D for the year 2000 survey (in French) and Annex A for more summary statistics on the data. Table 2 gives some statistics on the population in the 2006, 2007, 2008 and 2010 surveys. In these surveys I

\footnotetext{
${ }^{1}$ Data are available from The Réseau Quetelet, which provides researchers with French Data in social sciences, http://www.reseau-quetelet.cnrs.fr

${ }^{2}$ http://www.cnisf.org/

${ }^{3}$ If I compare it with the French Employment Survey, from the year 2003 to 2005 there are on average only 3,400 individuals a year graduated from a French engineer school in the French Employment Survey, against 25,000 engineers in the IESF survey, among which 10 on average work in the financial sector, against more than 800 in the IESF survey.
} 
Table 1

Data description

Total population and population working in the financial sector for each survey from 1983 to 2010

\begin{tabular}{lccc}
\hline Year & Total Population & Freq. in finance & Percent in finance \\
\hline 1983 & 25,712 & 336 & 1.3 \\
1986 & 30,132 & 503 & 1.7 \\
1989 & 32,993 & 588 & 1.8 \\
1992 & 30,550 & 491 & 1.6 \\
1995 & 20,588 & 294 & 1.4 \\
1998 & 23,353 & 360 & 1.5 \\
2000 & 28,698 & 382 & 1.3 \\
2004 & 25,846 & 520 & 2.0 \\
2005 & 32,303 & 606 & 1.9 \\
2006 & 39,863 & 821 & 2.1 \\
2007 & 46,290 & 903 & 2.0 \\
2008 & 41,937 & 759 & 1.8 \\
2010 & 39,417 & 833 & 2.1 \\
Total & 417,682 & 7,251 & 1.8 \\
\hline
\end{tabular}

can distinguish jobs in the financial sector thanks to the job description provided in the survey. I observe that wages are heterogeneous across jobs, and higher than in the rest of the economy for a lower level of experience.

There are three sources of selection bias in the data. First, respondents are volunteer and unfortunately, I do not know the response rate. Second, only half of alumni organizations have taken part in the survey. Thus, in 2008, whereas 220 schools provided an engineer degree, only 112 alumni organizations participated. I find that this restricted sample concerns most of top engineer schools. Indeed, based on 2010 Towers Perrin's ranking in terms of wages ${ }^{4}$, I find that the panel of participating engineer schools represents $75 \%$ of the 92 top engineer schools and that $71 \%$ of respondents are graduated from these top schools. Third, alumni organizations send the survey to alumni whose name and address they have. As a result, respondents are younger and more likely to be women than in the total population of engineers. However, I find that when controlling for observable characteristics such as age, experience and sex this bias is minimized (Annex B).

\subsection{The Financial Sector Premium}

The econometric strategy is the following. I observe compensation for employees aged more than 20 but less than 65 and in activity. The control variables include 8 education dummies among which 6 are indicators of the ranking of the engineer schools. The two other education dummies refer to double graduated engineers, first, in science, second, in management or economics. Demographic controls include sex, marital status and sex $\times$ marital status. I control for occupation with nine dummies, standing for production,

\footnotetext{
${ }^{4}$ Palmarès l'Expansion - Towers Perrin, 2009
} 
Table 2

Jobs in the financial sector: population, wage and experience - 2006-2010

For each financial profession, "Population" is the number of individuals, "Experience" the average number of years of experience, "Gross wage" the average gross compensation in 2005euros including bonuses, "\% Abroad" is the share of individuals working abroad

\begin{tabular}{lrrrr}
\hline Job & Population & Gross Wage & Experience & \% \\
\hline Analyst & 169 & 75,834 & 6 & 53 \\
Asset Management & 91 & 112,798 & 11 & 25 \\
Back Office & 20 & 92,251 & 12 & 20 \\
Controller & 60 & 59,973 & 8 & 5 \\
Executive & 149 & 228,223 & 17 & 48 \\
IT & 454 & 67,372 & 13 & 15 \\
Merger and Acq. & 37 & 174,583 & 9 & 30 \\
Other & 919 & 95,949 & 13 & 22 \\
Project Finance & 84 & 90,514 & 12 & 33 \\
Quant & 91 & 133,991 & 6 & 64 \\
Retail & 127 & 56,931 & 11 & 6 \\
Risk Management & 104 & 90,081 & 11 & 27 \\
Structurer & 146 & 157,020 & 8 & 38 \\
Trading and Sale & 249 & 259,231 & 9 & 55 \\
Rest of the Economy & 107,866 & 56,459 & 12 & 12 \\
\hline
\end{tabular}

logistics, development, IT, commercialization, administration, executive, education and else. There are five different dummies for the firm type: individual firm, private sector, public firm, public administration and others (non-governmental organization ect), and four dummies for the firm size: less than 20 employees, from 20 to 500, from 500 to 2000, more than 2000. The job characteristics are represented by a working in "Ile de France" dummy (Paris and region around Paris), a working abroad dummy (together with seven country dummies for the US, UK, Germany, Switz, Luxembourg, China and Belgium from 2004 on) and four hierarchical responsibility dummy, from no hierarchical responsability to chief executive. Finally, 48 industries are defined using the 2008 five-digit, the 2003 and 1993 four-digit NAF codes and the 1973 NAP codes, depending on the year of the survey. The objective is to have a manageable number of industries that cover most of engineer activities (Sectors are described in Appendix A). For engineers working abroad, I use the sector they declare working in when available.

Based on information on job satisfaction and hours worked, I can also control for working conditions from 2004 on. In a model of compensating wage differentials, workers with homogeneous preferences may be compensated for harder working conditions. I control for both stress and workload with two dummy variables which are coded one if the interviewee suffers from them, 0 if not. In addition, a variable indicates if the engineers work overtime occasionally, 5 to 10 hours or more than 10 hours.

The income data have two limitations. First, people are asked their wage which could lead to both measurement errors and bias. Concerning measurement errors, the risk is limited as the amount declared is closely defined: it is the gross salary declared on the tax declaration, and it includes variable compensation in the form of bonuses (but ex- 
cluding stock options). Moreover, I find that the data are in line with Towers Perrin's survey (Annex B). The second limitation is that I do not dispose of data on hours worked: income data concern the annual gross wage. As a result, a hourly wage cannot be computed. However, people declare if they work full time or not, and if not, they declare the percentage of a full time job their part time job corresponds to. Hence there are two possibilities: Either to reconstruct full time compensation, or to only work on data concerning full time jobs. To limit measurement errors, the choice made was to work only on full time employees. Hence, $10.8 \%$ of the variables are dropped. I also drop data that do not concern employees (unemployed or inactive), of individuals of 66 or more and of workers of less than 1 year of experience. Finally, for each year I stream data in the following way. First, I keep observation with compensation higher than the legal minimum wage. Second, for each sector I drop compensation in the top $1 \%$ of the distribution. All nominal quantities are converted into constant 2005euros, using the French National Price Index (IPCN) from INSEE ${ }^{5}$.

In order to assess the premium of working in the financial sector and compare it to other industries' wage differential, I test the following equation:

$$
w_{i, t}=X_{i, t} \beta+S_{i, t} \gamma+D_{t} \alpha+\epsilon_{i, t}
$$

where $w_{i, t}$ is the log yearly gross wage, $X_{i, t}$ is the vector of individual characteristics described above, $S_{i, t}$ stands for the vector of industry dummies, and $D_{t}$ for the vector of year dummies. $\epsilon_{i, t}$ is the error term. As each industry has a dummy variable and I impose that the sum of all the industry dummy coefficients is zero, the coefficient is the deviation from the weighted mean of wages in other sectors.

Results for the periods 1983-1989, 1995-2000 and 2005-2007 are presented in Annex D. I find that the premium in the financial sector increases from $15 \%$ in 1995-1998 up to $32 \%$ in the period 2005 - 2007. I observe only two other sectors with a premium significantly higher than $10 \%$ on average over the 1995 - 2007 sample : the oil industry $(13 \%)$ and consulting (13\% on average). On the contrary, agriculture, education and public administration offer compensation significantly more than $10 \%$ lower than the rest of the economy, even after controlling for the type of the firm (individual firm, private sector, state firm, state, other and year dummies).

Finally, I control for unemployment risk based on two types of variable. First, I use the 2009 labor turnover data from the French Ministery of Labor, Employment and Health. The fraction of layoffs on the total population of employees per sector is provided as a measure of unemployment risk. I find first that there is a negative correlation between wages and industry unemployment risk, second that from 1999 on unemployment risk has been constant in the financial sector (layoff rate of 1.7\%), third that the financial sector is one of the sector with the lowest layoff rate (average: $2.9 \%$ ). Second, I use a specific question of the survey asking interviewees if they suffer from job insecurity. If yes the variable is coded 1, 0 if not. Results are similar: the coefficient of this variable in wage equation (1) is significantly negative. I also do not find a positive significative impact of workload or stress on compensation.

\footnotetext{
${ }^{5}$ Data are available at http://www.imf.org/external/datamapper/index.php
} 


\subsection{The Increase in the Financial Sector Premium: 1983-2010}

As the survey covers a long period, from 1983 to 2010, I can estimate the evolution of the premium in the financial sector over 25 years. Controlling for the same variables as before when possible and estimating Wage Equation (1) each year, I find that the premium increases from $4.2 \%$ in 1986 up to $33 \%$ in 2007 (Figure 3). ${ }^{6}$

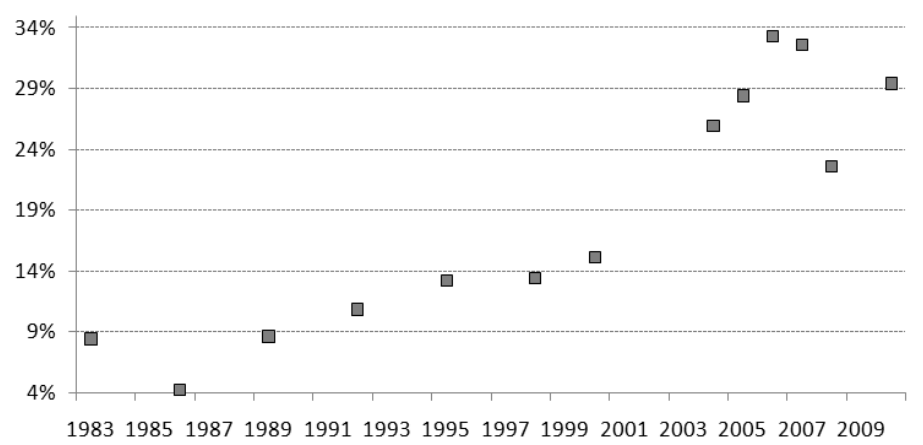

Figure 6

Evolution of the wage premium in the Financial Industry from 1983 to 2010.

Boxes represent the coefficient of the financial sector dummy in wage equation (1) for each year

As the premium amounts to $29 \%$ in the year 2010, against $23 \%$ in 2008 , the impact of the crisis has been restricted both in scale and over time. This is confirmed by a question of the 2010 survey. Interviewee are asked first whether the fixed wage is constant, has increased or decreased from 2009 and second the scale of the evolution. Only 11 interviewee in the financial sector have observed a decrease in fixed wage. The average increase in fixed wages is $7.1 \%$ against $4.2 \%$ in the rest of the economy. Concerning the variable share of wages, it has increased by $15.6 \%$ in the financial sector against $9 \%$ in the rest of the economy. After controlling for the same variables as in the wage equation, working in the financial sector implies a significant higher increase (at the $1 \%$ level) in the wage evolution by $1.7 \mathrm{pp}$.

Second, Figure 5 shows that the contribution of financiers to the top $1 \%$ of the income distribution has increased exponentially and much more rapidly than the share of financiers in the total sample. In 2007 they represent $56 \%$ of the top $1 \%$ against $3.6 \%$ of the total sample.

\footnotetext{
${ }^{6}$ One of the limitations of this result is that some control variables were not available across all surveys. More precisely, both in 1998 and 1995, I cannot control for the marital status, and in 1983 I can only control for one education dummy (top engineer school or not). However, I find that not controlling for these variables leads to an overestimation of the premium of less than $0.5 \%$. This is probably due to the fact that the only education variable that is kept absorbs most of the impact of education on wages, and that marital status is dominated by the gender dummy.
} 


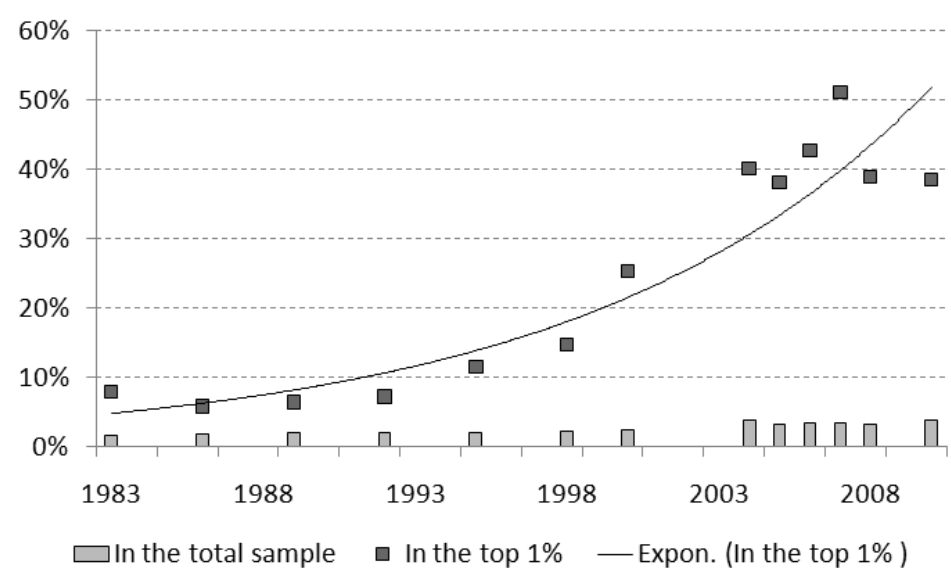

Figure 7

Evolution of the share of individuals working in the financial sector in the total sample and in the top $1 \%$ of the income distribution from 1983 to 2010

\section{Empirical Evidence}

\subsection{Wage Distribution Evidence}

\subsubsection{High Wage Heterogeneity and Skweness in the Financial Sector}

According to the model described above, if the financial sector premium is due to a higher sensitivity to talent, it should be coupled with a higher heterogeneity and skewness in the wage distribution.

First, to assess wage heterogeneity within sectors, I estimate Wage Equation 1 without the vector of sectoral dummies $S_{i, t}$ over the period 2005-2008. Then, I examine the distribution of residuals for each sector. With a standard deviation of residuals of 0.58 against an average of 0.26 in the rest of the economy, I find first that the financial sector is the sector with the highest variance in residuals (more than twice higher as in other sectors). Second, Figure 8 displays the distribution of residuals in the financial sector. It suggests that indeed the distribution is skewed to the right, which is confirmed by the skewness statistics. The latter amounts to 1.8 in the financial sector, against 1.2 in the rest of the economy. 


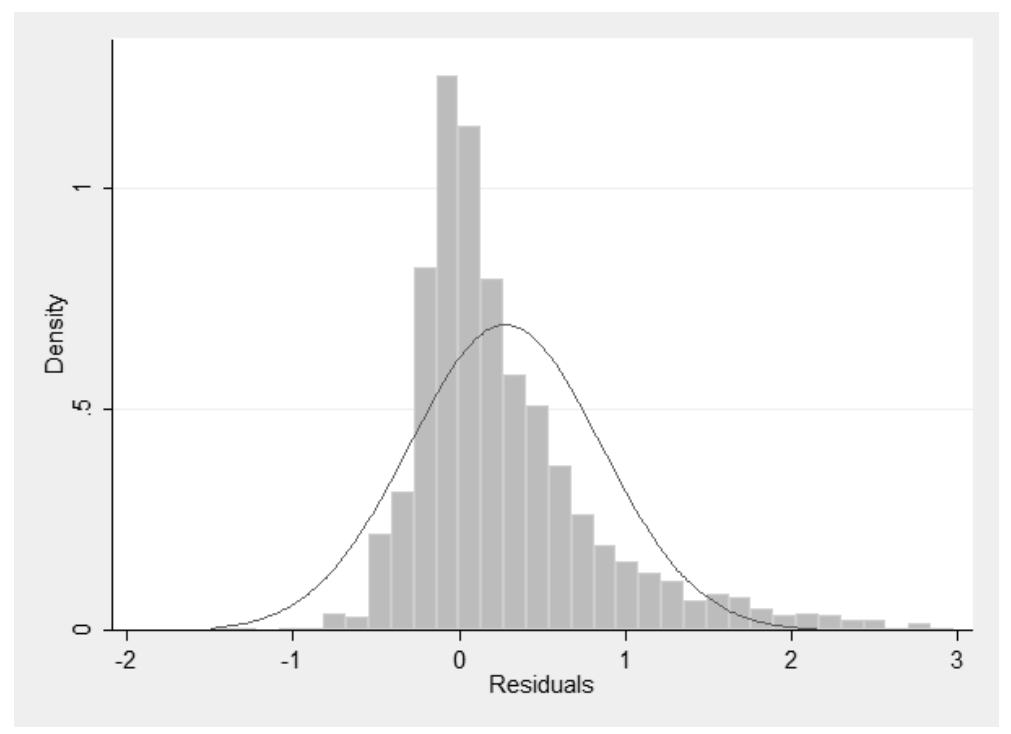

Figure 8

Residual distribution in the financial sector

(2,126 observations)

Finally, in the 2005, 2006 and 2007 surveys, I divide the total population in finance and in non-finance into 100 groups of equal size ranked by compensation. Figure 8 represents the share of the total wage bill captured by each group both in finance and in non finance. It shows that highest paid worker in finance capture a larger share of the total wage bill than worker in non finance.

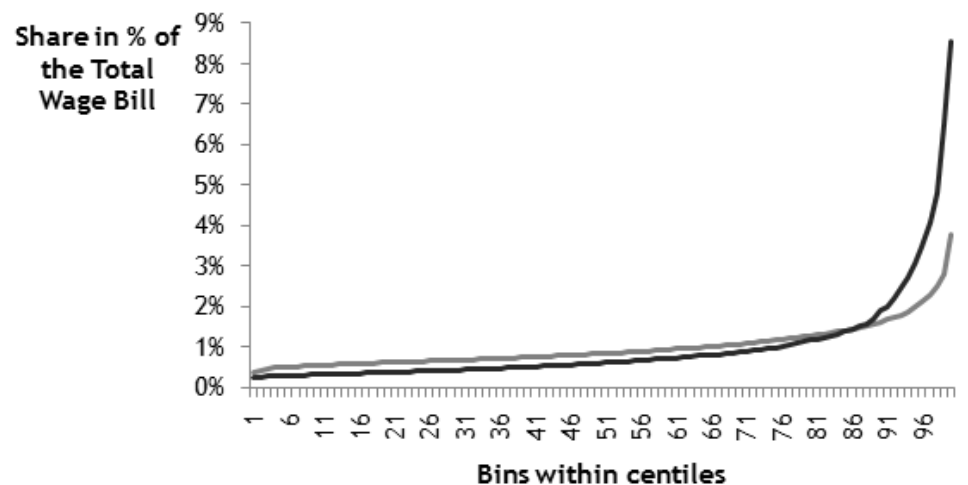

—Total Economy, Finance Excluded —Financial Sector

Figure 9

Share of the Total Wage Bill by Centiles

Wage equation (1) - 2005-2008 - 62,940 observations, 2126 in the financial sector 


\subsubsection{Quantile Regressions}

Finally, if the premium in the financial sector is due to a higher talent sensitivity, it should be higher in the top of the wage distribution. To test this assumption, I estimate the same wage equation as in section 1 by quantile regressions (Koenker and Basset, 1978). Rather than fitting the equation through the mean of the dependant variable, quantile regression considers the impact of the regressor at specific quantiles of the distribution of the dependant variable. Figure 8 describes the evolution of the premium in the financial sector across quantiles of the wage distribution.

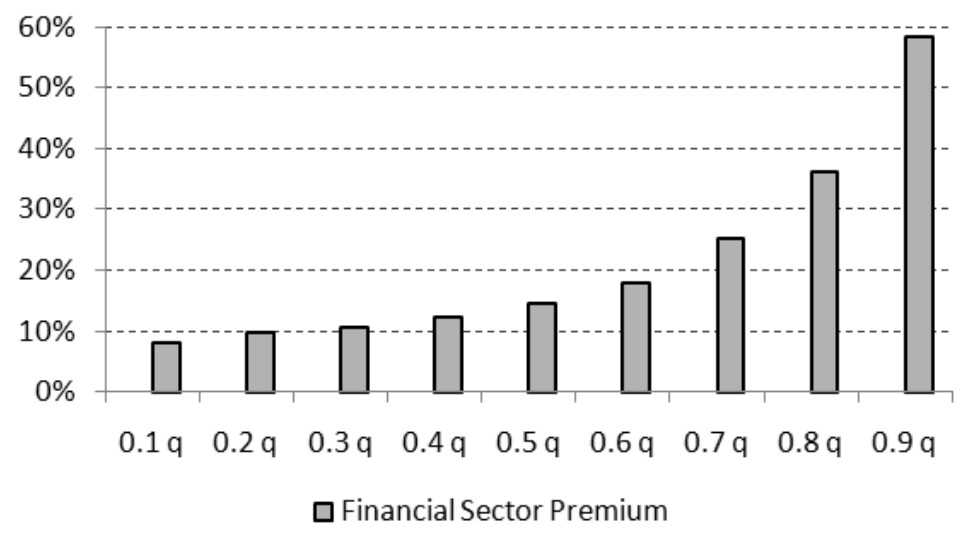

Figure 10

Evolution of the premium in the financial sector over quantiles of the wage distribution Wage Equation (1), Quantile Regressions - 2005-2010 - 92,541 observations, 3,187 in the financial sector

I find that in the financial sector the premium is more than 7 times as high at the top of the wage distribution ( 0.9 quantile) as at the bottom ( 0.1 quantile). Table $\mathrm{X}$ in annex displays the detailed result of this quantile regressions over sectors. I observe that on the contrary, in the oil and nuclear industries the premium is lower at the top than at the bottom of the wage distribution. The only industry which displays the same patterns is the consulting industry, with a premium 7 times as high at the top as at the bottom of the wage distribution.

\subsection{Career Dynamics Evidence}

The model predicts higher returns to experience in the first period of the career, an increasing premium and variance in wages over experience, and persistence in career in the financial sector.

\subsubsection{Evolution of the Premium over Careers}

Higher sensitivity to industry specific talent implies first, an increasing premium over the career, second an increasing variance in wages. 
Because the data are cross sectional, I cannot directly estimate the evolution of the premium over an individual's career. However, as respondents provide information on their work experience at the date of the survey, it is possible to compute an estimation of the evolution of the premium. For this purpose, I divide the samples of the 2006, 2007, 2008 and 2010 surveys into groups based on years of experience (less than two years, from 2 to 4 years, from 4 to 6 , from 6 to 8 and more). In order to deal with composition effects, each group is divided in subgroups based on the job: analyst, asset management, back office, controller, executive, it, merger and acquisition, project finance, quant, retail, risk management, structurer, trading. I then regress the log wage on sectorial dummies for each subgroup, using the same control variables as before. Finally, I estimate the impact of working in the financial sector by computing the contribution of each group times the average share of this group in the total population. The following figure shows the financial sector premium as a function of experience for the 25th, 50th and 75th percentiles of $\log$ (wage). Within group wage dispersion is captured by the difference between the 25th and 75th percentile, while the "standard"' return to education is summarized by the median. The figure suggests the premium in the financial sector increases over year of experience, which is consistent with a mecanism of talent revelation. Moreover, as the 75-50 gap has increased over time, there is also some evidence of increasing inequality in the upper tail within the financial sector.

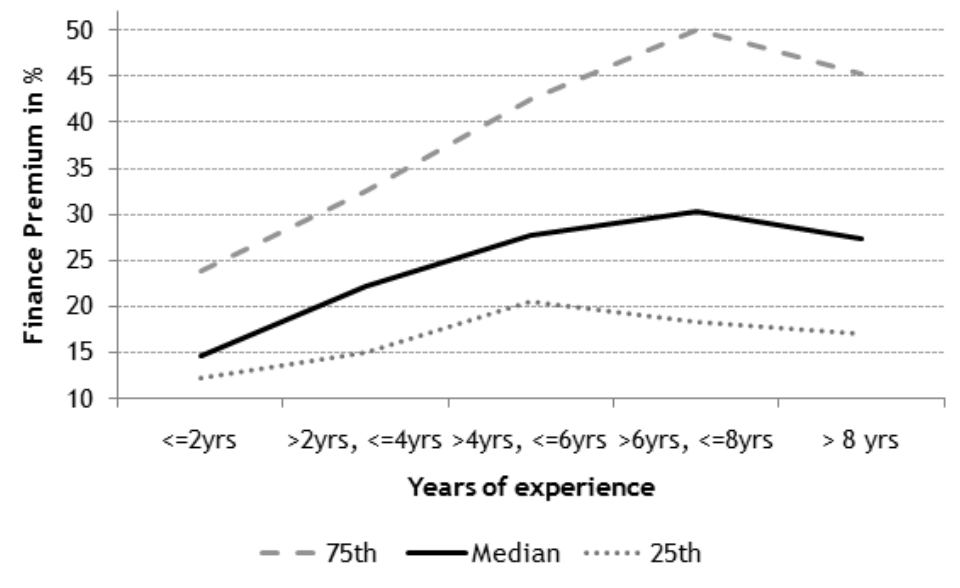

Figure 11

Financial Sector Premium by Years of Experience at the Median, 25th and 75th Wage Percentiles

2006-2010 - 77,696 observations with 2,549 individuals in the Financial Sector 


\subsubsection{Higher Return to Experience in the Financial Sector: Blinder Oaxaca Decomposition}

In order to explain to which extent the wage gap between the financial sector and the rest of the economy is due to higher returns to experience in the first period of the career, I use a Blinder-Oaxaca decomposition (Blinder, 1974; Oaxaca, 1973).

Table 6 gives the results of this decomposition over the years 2005-2010, using the rest of the economy as the reference group. As we assume that industry-specific talent is revealed over the first period of the career, results are displayed for two samples: workers with less than 10 years of experience and workers with less than five years of experience. I first observe that less than $25 \%$ of the wage differential is explained by difference in observable characteristics. Second, returns to experience explain $24 \%$ of the wage differential for individuals of less than 10 years of experience against more than $50 \%$ for individuals of less than 5 years of experience. As a result, returns to experience are higher at the beginning of the career in the financial sector and explain most of the wage differential.

Table 3

Blinder-Oaxaca Decomposition of the Premium:

Financial Sector versus Rest of the Economy

The dependant variable is the log of the yearly gross wage. Period 2005-2010

\begin{tabular}{|c|c|c|c|c|}
\hline & $\begin{array}{r}\text { Samp } \\
\leq 10 \text { years } \mathrm{o}\end{array}$ & $\begin{array}{l}\text { le } 1 \\
\text { experience }\end{array}$ & $\begin{array}{r}\text { Samp } \\
\leq 5 \text { years of }\end{array}$ & $\begin{array}{l}\text { e } 2 \\
\text { xperience }\end{array}$ \\
\hline Total Wage Gap (log) & 0.5 & & 0.4 & \\
\hline Decomposition & Endowments & Coefficients & Endowments & Coefficients \\
\hline Sexe & 0.00 & -0.02 & 0.00 & -0.01 \\
\hline Married & 0.00 & -0.02 & -0.00 & -0.04 \\
\hline Married*female & 0.00 & 0.00 & 0.00 & -0.00 \\
\hline Working abroad & 0.07 & 0.16 & 0.06 & 0.16 \\
\hline Experience & 0.01 & 0.13 & -0.00 & 0.26 \\
\hline Paris & 0.02 & 0.06 & 0.01 & 0.06 \\
\hline Top Engineer School & 0.01 & 0.04 & 0.01 & 0.04 \\
\hline Prep years & 0.00 & 0.09 & 0.00 & 0.10 \\
\hline Double degree in management & 0.01 & 0.01 & 0.01 & 0.01 \\
\hline Double degree in science & 0.00 & 0.06 & 0.00 & 0.05 \\
\hline Team manager & 0.00 & 0.03 & 0.00 & 0.02 \\
\hline Director & -0.01 & 0.00 & -0.00 & -0.00 \\
\hline Top executive & -0.00 & 0.00 & -0.00 & -0.00 \\
\hline Private sector & 0.00 & 0.04 & 0.00 & 0.01 \\
\hline Large firm & 0.01 & 0.06 & 0.02 & 0.07 \\
\hline Subtotals & 0.13 & 0.40 & 0.11 & 0.38 \\
\hline Total Observations & 48,5 & & 24,0 & \\
\hline Financial Sector & 1,7 & & 82 & \\
\hline Rest of the economy & 46,8 & & 24,2 & \\
\hline $\mathrm{R}$ squared & 0.48 & & 0.3 & \\
\hline
\end{tabular}

\subsection{Size Effects and Compensation}

In a competitive assignment model between talent and firms, if heterogeneity in firm fixed effects is sufficiently low, a worker's wage depends both on the size of his job and the 
aggregate capital per employee within the industry. To test this assumption, I compute the average asset value per employee for the largest 50 firms of each sector over the period 1982-2010. As in Gabaix and Landier (2008), I use the firm's total market value as a proxy for firm size. Based on Compustat data for the U.S. economy, the formula is:

$$
\text { mktvalue }=\text { data } 199 * \text { abs }(\text { data } 25)+\text { data } 6-\text { data60 }- \text { data74 }
$$

All nominal quantities are converted in constant 2005 dollars, using the GDP deflator from the Bureau of Economic Analysis.

I run the following cross-industry regression for individual $i$ in sector $j$ :

$$
w_{i, j}=c+\eta \ln \left(Y_{i}\right)+\alpha \ln (\operatorname{mcap})_{j}+\beta X_{i}
$$

mcap is the market capitalization in the year 2010. Table X provide estimates of the coefficient of this OLS regression with $t$-stat clustered at the sector level. The results are consistent with the model: both project size and the average size per employee at the industry level are significant determinants of worker compensation.

Table 4

Ln(Compensation)

Wages in the 2010 survey

\begin{tabular}{lrr}
\hline & $(\mathbf{1})$ & $\mathbf{( 2 )}$ \\
\hline Ln(Size) & 0.10 & 0.04 \\
& $(0.006)$ & $(0.005)$ \\
Ln(Market Cap per Employee) & 0.08 & 0.06 \\
& $(0.02)$ & $(0.02)$ \\
Sexe & & -0.06 \\
& & $(0.02)$ \\
Married & 0.04 \\
& & $(0.008)$ \\
Working Abroad & 0.38 \\
& & $(0.04)$ \\
Experience & & 0.05 \\
& & $(0.02)$ \\
Experience Squared & & -0.00 \\
& & $(0.00)$ \\
Top Engineer Schools & & 0.13 \\
& & $(0.03)$ \\
Prep Years & & 0.05 \\
& & $(0.08)$ \\
\hline Responsability Dummies & No & Yes \\
Size Dummies & No & Yes \\
Occupation Dummies & No & Yes \\
Observations & 6,374 & 5,076 \\
$R^{2}$ & 0.29 & 0.69 \\
\hline & &
\end{tabular}


The model predicts that the higher sensitivity to industry-specific talent the more correlated is capital per employee with wages within the sector. Indeed, industry fixed effects are lower relatively to the size of adjustable capital and its impact on wages. As a result, the premium in the industry can be explained by an industry specific correlation between wages and capital per worker. To test this assumption, I introduce interaction effects between size and industry in Wage Equation 1:

$$
w_{i, t}=c+\beta X_{i, t}+\eta \ln \left(Y_{i, t}\right)+\gamma S_{i, t}+\lambda \ln \left(Y_{i, t}\right) \times S_{i, t}+\epsilon_{i, t}
$$

I drop individuals in sectors in which the number of observations is lower than 40 . There is a total of 6,344 individuals left in 31 sectors. Table $\mathrm{X}$ reports the result of the regression. It seems that indeed a size effect explains the rpemium in the financial sector. 


\section{Table 5}

The dependant variable is the log of the yearly gross wage - Each industry has a dummy variable - Decomposition in 33 sectors - 2010, 6825 individuals

The model includes a female dummy, a married dummy, a female $\times$ married dummy, a Paris area dummy, 7 education dummies, a working abroad dummy, years of professional experience and its square, 4 hierarchic responsibility dummies, 9 occupation dummies, 4 firm size dummies, 4 firm type dummies .

\begin{tabular}{|c|c|c|c|c|c|c|}
\hline \multirow[b]{3}{*}{ Industry } & \multirow{2}{*}{\multicolumn{2}{|c|}{$\begin{array}{c}\text { Model 1 } \\
\text { Gross Differences }\end{array}$}} & \multicolumn{4}{|c|}{$\begin{array}{ll}\text { Model 2 } \\
\end{array}$} \\
\hline & & & \multicolumn{2}{|c|}{ Interaction Coef } & \multicolumn{2}{|c|}{ Industry Dummy Coef } \\
\hline & Coef. & (Std. Err.) & Coef. & (Std. Err.) & Coef. & (Std. Err.) \\
\hline $\operatorname{Ln}($ Size $)$ & & & 0.04 & $(0.003)$ & & \\
\hline aero & -0.111 & $(0.018)$ & -0.019 & $(0.008)$ & -0.533 & $(0.580)$ \\
\hline auto & -0.086 & $(0.016)$ & -0.019 & $(0.008)$ & -0.523 & $(0.580)$ \\
\hline chemicals & 0.011 & $(0.021)$ & 0 & $(0.009)$ & -0.699 & $(0.585)$ \\
\hline construction & -0.096 & $(0.015)$ & 0.007 & $(0.009)$ & -0.945 & $(0.585)$ \\
\hline consulting & 0.144 & $(0.023)$ & 0.042 & $(0.012)$ & -1.115 & $(0.591)$ \\
\hline drugs & 0.03 & $(0.031)$ & -0.001 & $(0.014)$ & -0.675 & $(0.608)$ \\
\hline education & -0.145 & $(0.065)$ & -0.062 & $(0.042)$ & 0 & $(0.000)$ \\
\hline eleq & -0.072 & $(0.022)$ & -0.002 & $(0.010)$ & -0.731 & $(0.586)$ \\
\hline electric & 0.081 & $(0.025)$ & -0.033 & $(0.011)$ & -0.144 & $(0.592)$ \\
\hline electronic & -0.083 & $(0.016)$ & -0.006 & $(0.008)$ & -0.695 & $(0.581)$ \\
\hline engineering & -0.078 & $(0.012)$ & -0.013 & $(0.006)$ & -0.589 & $(0.573)$ \\
\hline finance & 0.462 & $(0.023)$ & 0.092 & $(0.010)$ & -1.718 & $(0.592)$ \\
\hline food & -0.013 & $(0.022)$ & -0.016 & $(0.009)$ & -0.48 & $(0.585)$ \\
\hline holding & 0.151 & $(0.021)$ & 0.03 & $(0.009)$ & -1.041 & $(0.585)$ \\
\hline it & -0.026 & $(0.017)$ & 0.022 & $(0.009)$ & -1.033 & $(0.582)$ \\
\hline machin & -0.042 & $(0.018)$ & 0.005 & $(0.008)$ & -0.823 & $(0.582)$ \\
\hline media & 0.075 & $(0.034)$ & 0.064 & $(0.021)$ & -1.556 & $(0.653)$ \\
\hline metal & -0.075 & $(0.026)$ & -0.008 & $(0.013)$ & -0.655 & $(0.603)$ \\
\hline mining & 0.106 & $(0.035)$ & 0.005 & $(0.013)$ & -0.733 & $(0.608)$ \\
\hline service & 0.079 & $(0.036)$ & 0.014 & $(0.015)$ & -0.836 & $(0.610)$ \\
\hline oil & 0.033 & $(0.046)$ & -0.035 & $(0.022)$ & -0.146 & $(0.666)$ \\
\hline orga & 0.005 & $(0.037)$ & & 0 & $(0.000)$ & \\
\hline plastic & -0.02 & $(0.028)$ & 0.029 & $(0.012)$ & -1.15 & $(0.597)$ \\
\hline public & -0.096 & $(0.100)$ & 0.001 & $(0.048)$ & -0.776 & $(0.872)$ \\
\hline realestate & -0.025 & $(0.048)$ & -0.041 & $(0.024)$ & -0.142 & $(0.688)$ \\
\hline ship & -0.055 & $(0.033)$ & -0.02 & $(0.014)$ & -0.481 & $(0.611)$ \\
\hline soap & 0.06 & $(0.031)$ & 0.025 & $(0.015)$ & -1.049 & $(0.615)$ \\
\hline steel & -0.009 & $(0.027)$ & -0.006 & $(0.013)$ & -0.635 & $(0.601)$ \\
\hline telecom & -0.043 & $(0.025)$ & -0.008 & $(0.011)$ & -0.63 & $(0.592)$ \\
\hline transp & -0.05 & $(0.029)$ & -0.027 & $(0.012)$ & -0.343 & $(0.598)$ \\
\hline utilities & -0.108 & $(0.035)$ & -0.033 & $(0.020)$ & -0.331 & $(0.648)$ \\
\hline wholesale & 0.001 & $(0.018)$ & 0.013 & $(0.009)$ & -0.912 & $(0.583)$ \\
\hline Observations & & 6,816 & & &, 816 & \\
\hline$R^{2}$ & & 0.68 & & & 0.72 & \\
\hline
\end{tabular}

I find that within individuals declaring project size, senstivity to talent account for inter industry wage differential. Figure X illustrates the correlation between the coefficient of the interaction terms and the coefficient of the sector dummies. 


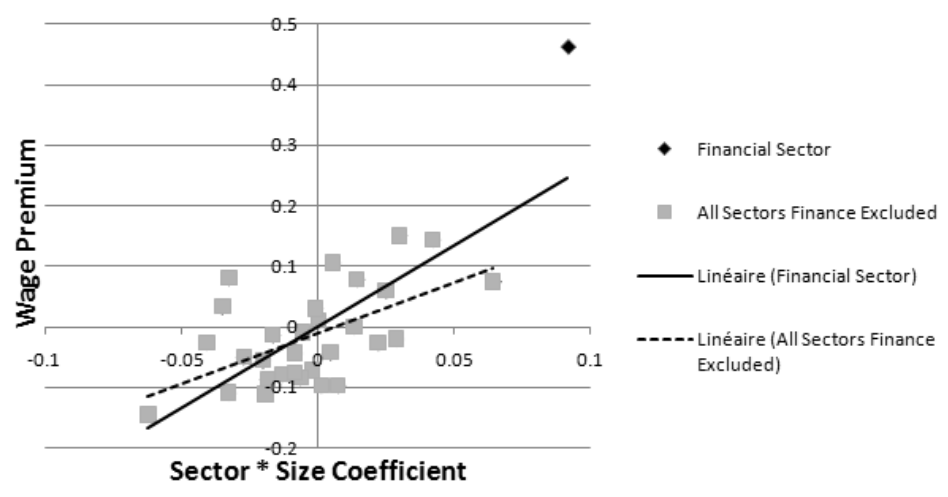

Figure 12

Coefficient of the Interaction and Premium across Sectors

\subsection{Time Series Evidence}

According to the model, the increase in compensation in the financial sector may be explained by an increase in sensitivity to talent. The latter would imply an increase in project size per employee. In order to assess whether a size effect has came along with the increase in compensation in the financial sector, I compute the average asset value per employee in the financial sector for the largest 50 firms of the sector over the period 1982-2008 using the same method as above. As Figure X displays, it seems that indeed the premium has increased along with project size per employee.

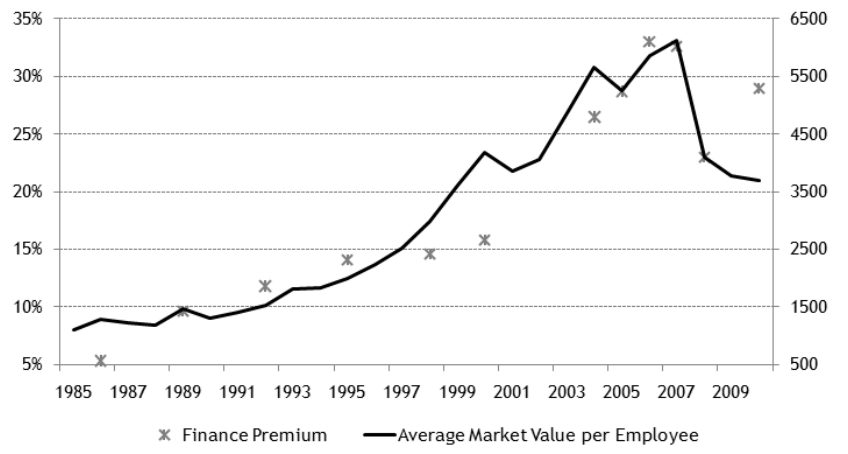

Figure 13

Average Market Value per Employee in million 2005dollars in the Financial Sector and Evolution of the Premium (1983 - 2008)

Firm size is the median market value of the top 50 firms in the U.S. financial sector in billion $2005 \$$, computed using compustat

If the premium has increased due to a higher sensitivity to talent, gains should be higher at the top of the wage distribution. Figure X shows quantile regressions estimate of the wage premia at the 10th, 50th and 90th percentile over three periods: 1983-1989, 
1995-2000 and 2005-2007. The figures illustrates that gains at the 10th or 50th percentile of the wage distributions are much smaller compared with gain at the 90th percentile, which is consistent with increasing superstar effects.

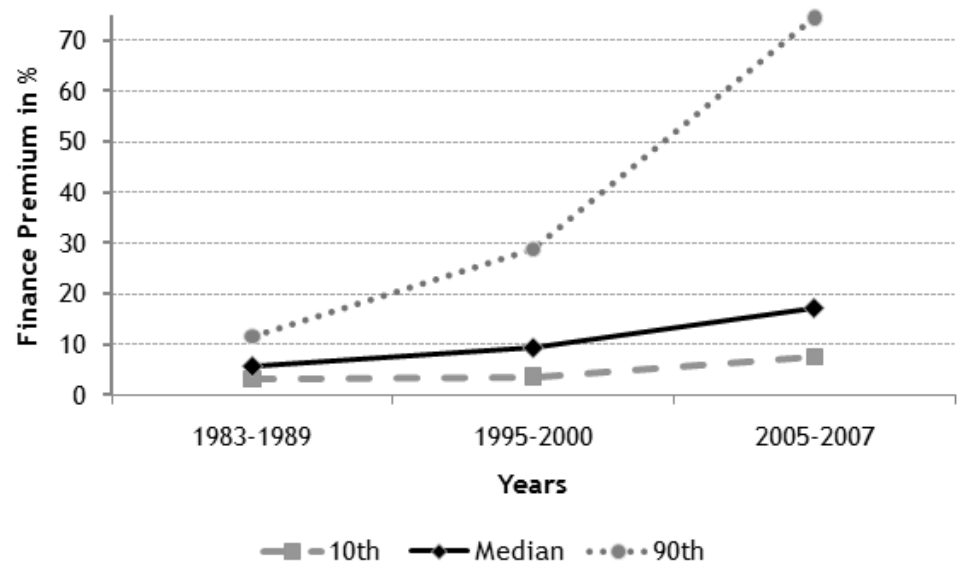

Figure 14

Evolution of the Finance Premium over Quantiles

The model predicts that the increase in the premium should be correlated with firm profitability. Figure X displays the increase in 8 biggest French banks EBITDA and shows that this empirical prediction is confirmed.

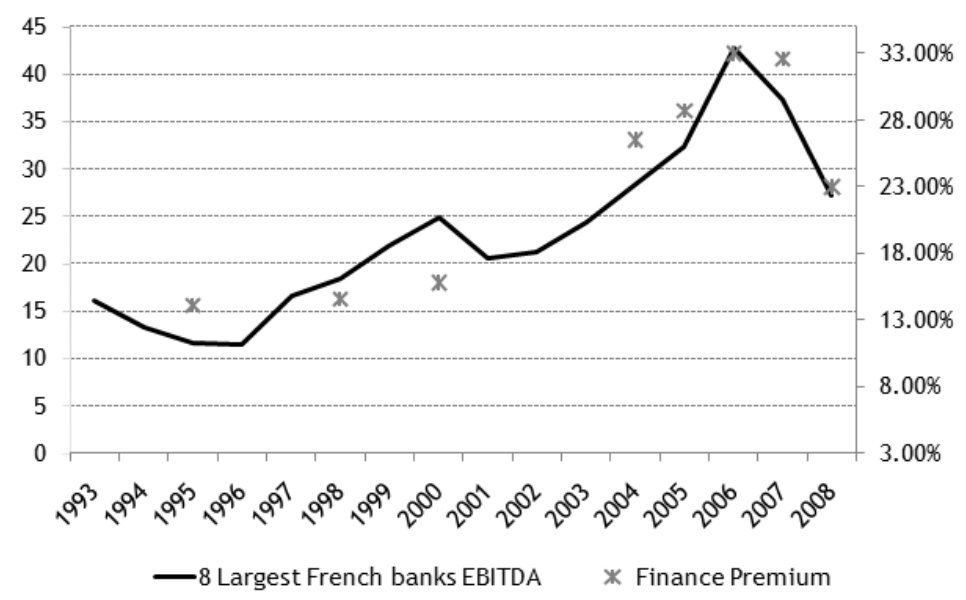

Figure 15

Evolution of the EBITDA in constant 2005euros for the 8 French Largest Banks and the Finance premium (1993-2008)

Source: French Commission Bancaire

Finally, according to the model (Proposition 6), if superstar effects are due to deregulated finance, the size of this subsector should have increase over time. I use the fraction of off-balence sheet activities over total assets as a proxy for the size of the deregulated 
finance sector. Figure $\mathrm{X}$ describes the correlated evolution of the premium and the offbalance sheet ratio.

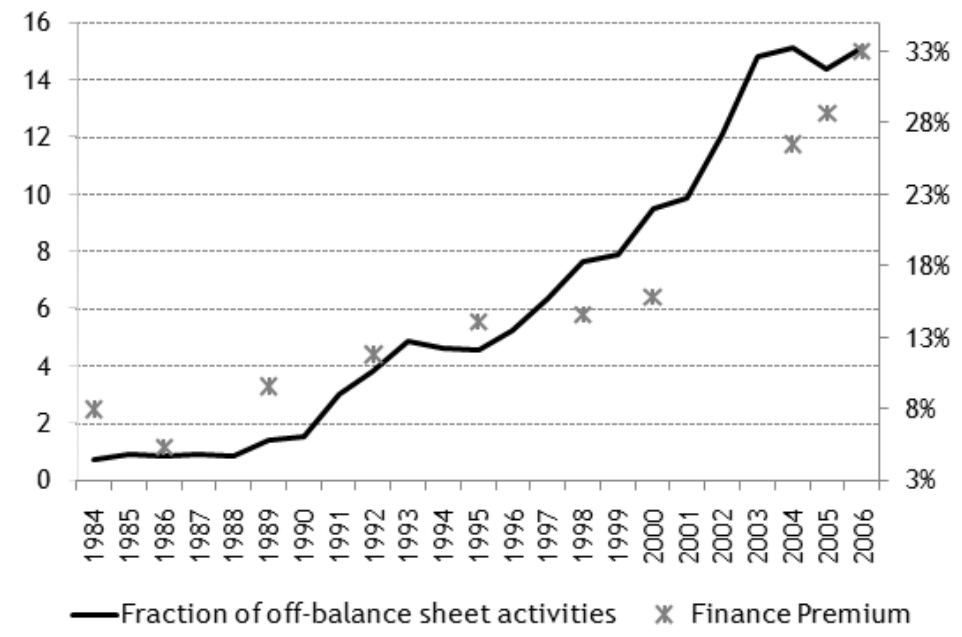

Figure 16

Evolution of the fraction of off-balance sheet activities to total assets in the French Financial Sector and the Finance Premium (1983-2006)

Source: French Commission Bancaire

\subsection{Variable Compensation Evidence}

\subsubsection{The Large Use of Variable Compensation in the Financial Sector}

One of the specificities of the CNISF survey is that it provides some information on the compensation structure. Interviewees are asked to provide the percentage of total compensation which is variable from the year 2000 survey onwards. As stock options are not included in total compensation, the variable share includes only bonuses and firm specific incentive schemes. I drop values higher than $80 \%$ of the total annual compensation ( $1 \%$ of the sample) and lower than 0 . Whereas $41 \%$ of individuals declare variable compensation in the total economy, they are $65 \%$ in the financial sector. When I regress the probability of declaring variable compensation over individual characteristics, I find that working in the financial sector increases the probability by $0.11 \mathrm{pp}$. Figure $\mathrm{x}$ gives the evolution of the average share of variable compensation that is declared in the financial sector and in the rest of the economy over the period 2000 - 2010. As the model predicts, the share of variable compensation is higher in the financial sector than in the rest of the economy. 


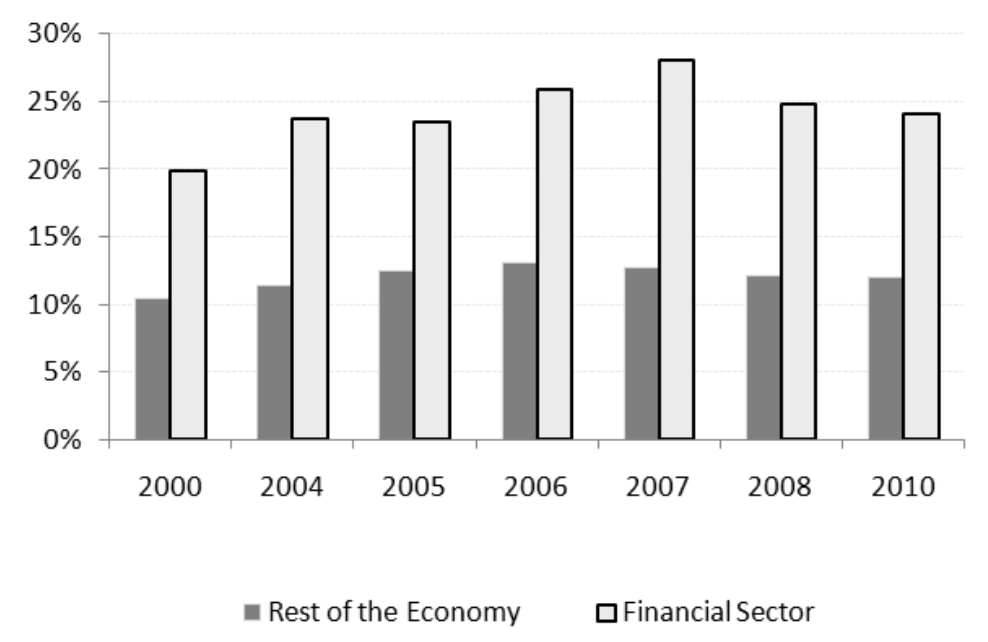

Figure 17

Evolution of the Ratio of variable compensation to total compensation in \%. 2000 $-2010$

Table 4 describes the evolution of the share of variable compensation with deciles of revenue within the financial sector and in the rest of the economy. Deciles are computed in 2000, 2004, 2005, 2006, 2007 and 2008. It suggests that part of the premium of top wages is paid through variable compensation, more in the financial sector than in the rest of the economy. 
Table 6

Ratio of variable compensation to total compensation across wage deciles

\begin{tabular}{lcc}
\hline Decile & Financial Sector & Rest of the economy \\
\hline 1 & $11.2 \%$ & $9.6 \%$ \\
2 & $12.1 \%$ & $8.4 \%$ \\
3 & $14.3 \%$ & $8.4 \%$ \\
4 & $15.9 \%$ & $8.7 \%$ \\
5 & $18.1 \%$ & $9.3 \%$ \\
6 & $21.8 \%$ & $9.7 \%$ \\
7 & $28.3 \%$ & $10.5 \%$ \\
8 & $30.2 \%$ & $11.6 \%$ \\
9 & $42.4 \%$ & $13.3 \%$ \\
10 & $58.1 \%$ & $19.9 \%$ \\
\hline
\end{tabular}

\subsubsection{Variable Compensation, Premium and Profits}

The model predicts first, that variable compensaiton increases with the premium in the financial sector, second, with the market size per employee. Finally, I create a new variable $w_{\text {fixed }}$ such that:

$$
w_{\text {fixed }}=(1-\operatorname{var} / 100) \times w
$$

which is the fixed part of the compensation declared in the survey. I regress the log of this new variable on the control variables described above and the sector dummy variables. There are 58,023 observations covering the years 2000, 2002 and 2004 - 2008. I obtain the following result. The premium in the financial sector is still significant, but amounts only to $5.3 \%$. It is now lower than in other sectors such as oil industry (11\%), nuclear industry (10\%), consulting (10\%) and mining (9\%). Figure 8 shows that the increase in the premium from the year 2000 to 2008 is due to an increase in variable compensation.

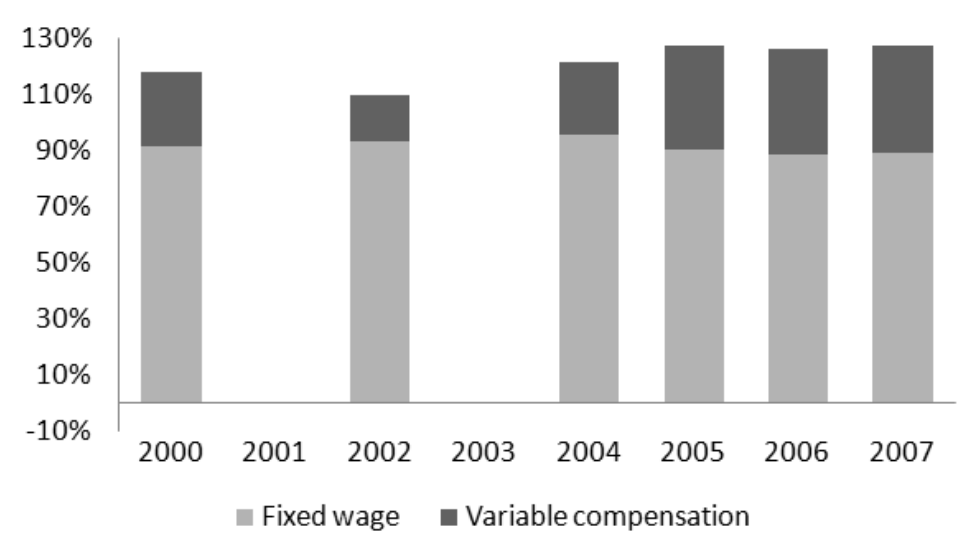

Figure 18

Decomposition across time between fixed and variable compensation in the financial sector, relatively to the rest of the economy. $2000-2007$ 
According to the model, variable compensation should increase in line with profits and be indexed on the overall performance of the firm. I find that variable compensation is highly correlated with bank profits. Figure 18 shows that the variable share has evolved in line with banks profits from 2000 to 2008.

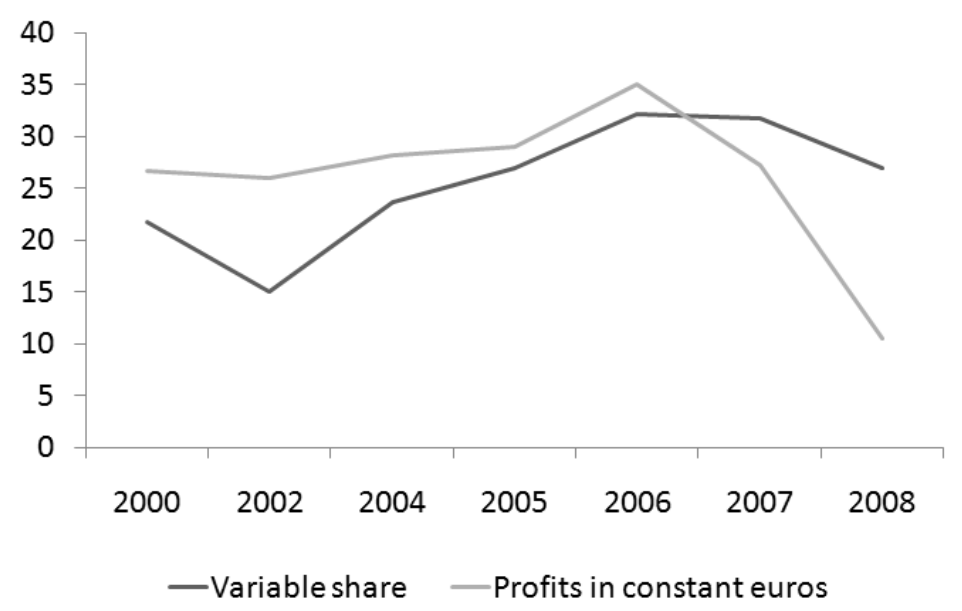

Figure 19

The evolution of the variable share (in \%) and profits in the financial sector (in billion of constant euros) - 2000-2008 - Data are from the French Commission Bancaire

\section{Conclusion}

Employees in investment banking are paid $60 \%$ more than they would be in other sectors of the economy. If I consider the financial sector as a whole, the premium amounts to $33 \%$ in 2007 and results from an increase from 1980 on. I find that competition for industry specific talent may account for this premium. In a historical perspective, technological progress and finance deregulation would have made skills in the financial sector more general within the sector but more industry-specific, increasing competition for the best employees in the sector. They may have also increased the sensitivity of profits to talent. This result has implications concerning wage inequalities, talent allocation, risk taking and their impact on growth. It predicts that regulating the structure of compensation in the financial sector, restricting bonuses for example, may have no impact on the level of compensation. Progressive income taxation may rather be a solution to the problems of talent misallocation or wage inequalities. Rents would be lower with long term contracts and transfer payments. Higher sensitivity to talent may be due to higher risk. 


\section{References}

Axelson, U. and P. Bond (2009). Investment banking (and other high profile) careers. Working Paper.

Bell, B. and J. Van Reenen (2010). Bankers' Pay and Extreme Wage Inequality in the UK. CEPR Working Paper.

Berk, J. and R. Green (2004). Mutual Fund Flows and Performance in Rational Markets. Journal of Political Economy 112(6), 1269-1295.

Biais, B., J.-C. Rochet, and P. Woolley (2009). The Lifecycle of the Financial Sector and Other Speculative Industries. CEPR Working Paper Series.

Clarke, J., A. Khorana, A. Patel, and R. Rau (2007). The impact of all-star analyst job changes on their coverage choices and investment banking deal flow. Journal of Financial Economics 84, 713-737.

Gabaix, X. and A. Landier (2008). Why has CEO pay increased so much? The Quarterly Journal of Economics February, 49-100.

Godechot, O. (2008). "Hold-up in finance": the conditions and possibility for high bonuses in the financial industry. Revue française de sociologie 47(2), 341-371.

Godechot, O. (2011). Finance and the rise of inequalities in France. Working Paper.

Goldin, C. and L. Katz (2008). Transitions: Career and Family Life Cycles in the Educational Elite. American Economic Review: Papers 83 Proceedings 98(2), 363-369.

Holmström, B. (1982). Moral Hazard in Teams. The Bell Journal of Economics XIII(2), $324-340$.

Kaplan, S. and J. Rauh (2009). Wall Street and Main Street: What Contributes to the Rise in the Highest Income? The Review of Financial Studies.

Kostovetsky, L. (2009). Are Mutual Funds Losing Their Best Minds? Working Paper.

Murphy, K., A. Shleifer, and R. Vishny (1991). The Allocation of Talent: Implications for Growth. The Quarterly Journal of Economics May, 503-530.

Oyer, P. (2008). The Making of an Investment Banker: Stock Market Shocks, Career Choice, and Lifetime Income. The Journal of Finance LXIII(6), 2601-2628.

Philippon, T. and A. Reshef (2009). Wages and Human Capital in the US Financial Industry. NBER Working Paper.

Rosen, S. (1981). The Economics of Superstars. The American Economic Review 71(5), $845-858$.

Saint-Paul, G. (2008). Innovation and Innequality: How Does Technical Progress Affect Workers? Princeton University Press. 
Terviö, M. (2009a). Overworked and Overpaid: Failure in the Market for Job Experience. Working Paper.

Terviö, M. (2009b). Superstars and Mediocrity: Market Failures in the Discovery of Talent. Review of Economic Studies 72(2), 829-850. 


\section{A Summary Statistics}

\section{Table 7}

Summary Statistics on Personal Data across Years (1983 - 2010)

Mean or Frequence ratio. The sample age decreases over time, whereas the number of women increases.

\begin{tabular}{lrrrrr}
\hline Year & Age & Gender & Married & N. Children & Working Couple \\
\hline 1983 & 38.83 & 0.05 & 0.81 & 1.91 & \\
1986 & 38.34 & 0.07 & 0.78 & 1.67 &. \\
1989 & 38.00 & 0.07 & 0.75 & 1.75 &. \\
1992 & 39.24 & 0.10 & 0.79 & 1.80 & 0.60 \\
1995 & 39.21 & 0.10 & 0.68 & 1.61 &. \\
1998 & 37.58 & 0.13 &. &. & 0.73 \\
2000 & 36.97 & 0.17 & 0.71 &. & 0.78 \\
2004 & 34.14 & 0.15 & 0.76 & 1.17 & 0.81 \\
2005 & 34.20 & 0.14 & 0.77 & 1.18 & 0.82 \\
2006 & 34.32 & 0.15 & 0.77 & 1.17 & 0.82 \\
2007 & 34.07 & 0.16 & 0.76 & 1.07 & 0.81 \\
2008 & 34.63 & 0.16 & 0.77 & 1.13 & 0.83 \\
2010 & 35.20 & 0.17 & 0.77 & 1.11 & 0.78 \\
Total & 36.33 & 0.13 & 0.76 & 1.39 & \\
\hline
\end{tabular}

Table 8

Summary Statistics on Education across Years (1983 - 2010)

Frequence ratio

\begin{tabular}{lrrrr}
\hline Year & Prep Years & Top10 Eng. Sch. & D. Deg. Management & D. Deg. Science \\
\hline 1983 & $\cdot$ & 0.23 & $\cdot \cdot$ &. \\
1986 &. & 0.17 & 0.08 & 0.10 \\
1989 &. & 0.13 & 0.09 & 0.12 \\
1992 & 0.39 & 0.10 & 0.01 & 0.03 \\
1995 & 0.65 & 0.15 & 0.09 & 0.03 \\
1998 & 0.61 & 0.15 & 0.16 & 0.19 \\
2000 & 0.56 & 0.17 & 0.12 & 0.25 \\
2004 & 0.54 & 0.14 & 0.13 & 0.25 \\
2005 & 0.55 & 0.13 & 0.14 & 0.27 \\
2006 & 0.53 & 0.13 & 0.14 & 0.23 \\
2007 & 0.54 & 0.13 & 0.15 & 0.26 \\
2008 & 0.53 & 0.13 & 0.15 & 0.29 \\
2010 & 0.54 & 0.14 & 0.12 & 0.19 \\
Total & 0.54 & 0.15 & &
\end{tabular}


Table 9

Summary Statistics on Job Occupation across Years (1983 - 2010)

Mean or Frequence ratio. The sample age decreases over time, whereas the number of women increases.

\begin{tabular}{lrrrrrrrrr}
\hline Year & Production & Dev & IT & Sales & Adm & Executive & Education & Logistics & Other \\
\hline 1983 & 0.18 & 0.32 & 0.06 & 0.13 & 0.12 & 0.06 & 0.00 & 0.03 & 0.11 \\
1986 & 0.18 & 0.35 & 0.07 & 0.12 & 0.09 & 0.06 & 0.02 & 0.04 & 0.08 \\
1989 & 0.16 & 0.33 & 0.08 & 0.12 & 0.07 & 0.06 & 0.00 & 0.03 & 0.14 \\
1992 & 0.13 & 0.38 & 0.12 & 0.14 & 0.06 & 0.05 & 0.03 & 0.06 & 0.03 \\
1995 & 0.14 & 0.33 & 0.10 & 0.12 & 0.06 & 0.09 & 0.03 & 0.05 & 0.08 \\
1998 & 0.12 & 0.33 & 0.14 & 0.10 & 0.06 & 0.07 & 0.03 & 0.11 & 0.03 \\
2000 & 0.11 & 0.38 & 0.16 & 0.07 & 0.05 & 0.07 & 0.02 & 0.10 & 0.02 \\
2004 & 0.17 & 0.33 & 0.19 & 0.10 & 0.05 & 0.05 & 0.01 & 0.06 & 0.04 \\
2005 & 0.16 & 0.32 & 0.20 & 0.10 & 0.04 & 0.05 & 0.01 & 0.08 & 0.04 \\
2006 & 0.16 & 0.33 & 0.20 & 0.10 & 0.04 & 0.05 & 0.01 & 0.08 & 0.03 \\
2007 & 0.17 & 0.38 & 0.18 & 0.10 & 0.04 & 0.04 & 0.01 & 0.08 & 0.00 \\
2008 & 0.17 & 0.38 & 0.18 & 0.10 & 0.04 & 0.04 & 0.01 & 0.08 & 0.00 \\
2010 & 0.15 & 0.38 & 0.16 & 0.09 & 0.04 & 0.05 & 0.01 & 0.07 & 0.03 \\
Total & 0.15 & 0.35 & 0.15 & 0.11 & 0.06 & 0.06 & 0.01 & 0.07 & 0.05 \\
\hline
\end{tabular}

Table 10

Summary Statistics on Total Yearly Compensation in 2005euros

Compensation above the 99th centiles per sector and below the legal minimum wage has been dropped

\begin{tabular}{lrrrrr}
\hline Year & Mean & S.d. & p10 & p50 & p90 \\
\hline 1983 & 63,706 & 28,570 & 34,037 & 57,358 & 102,909 \\
1986 & 63,013 & 31,190 & 34,135 & 54,705 & 102,406 \\
1989 & 62,040 & 26,650 & 35,236 & 55,549 & 99,491 \\
1992 & 63,694 & 28,983 & 36,205 & 56,926 & 100,931 \\
1995 & 65,871 & 34,911 & 33,231 & 57,304 & 109,320 \\
1998 & 61,619 & 33,105 & 32,467 & 52,181 & 103,542 \\
2000 & 60,037 & 35,808 & 32,020 & 49,715 & 101,116 \\
2004 & 58,772 & 42,753 & 30,569 & 47,645 & 97,819 \\
2005 & 58,235 & 39,789 & 30,680 & 47,283 & 97,000 \\
2006 & 57,211 & 41,849 & 30,419 & 46,439 & 94,201 \\
2007 & 56,867 & 38,950 & 30,903 & 46,354 & 93,964 \\
2008 & 56,929 & 37,005 & 30,893 & 46,808 & 93,615 \\
2010 & 57,354 & 36,845 & 30,552 & 46,160 & 95,597 \\
Total & 60,022 & 35,726 & 31,926 & 50,400 & 99,146 \\
\hline
\end{tabular}


Table 11

Frequence by sectors

\begin{tabular}{|c|c|c|}
\hline Variable & Mean & Std. Dev. \\
\hline agriculture & 0.005 & 0.067 \\
\hline air & 0.004 & 0.064 \\
\hline alcohol & 0.004 & 0.065 \\
\hline auto & 0.053 & 0.225 \\
\hline carsale & 0.001 & 0.038 \\
\hline cement & 0.008 & 0.088 \\
\hline chemicals & 0.032 & 0.177 \\
\hline construction & 0.048 & 0.213 \\
\hline consulting & 0.043 & 0.202 \\
\hline drugs & 0.014 & 0.119 \\
\hline education & 0.009 & 0.097 \\
\hline eleq & 0.034 & 0.18 \\
\hline electric & 0.033 & 0.178 \\
\hline electronic & 0.077 & 0.266 \\
\hline engineering & 0.138 & 0.345 \\
\hline finance & 0.026 & 0.159 \\
\hline food & 0.022 & 0.147 \\
\hline fretail & 0.002 & 0.043 \\
\hline furniture & 0.004 & 0.065 \\
\hline glass & 0.006 & 0.074 \\
\hline health & 0.002 & 0.044 \\
\hline holding & 0.017 & 0.129 \\
\hline insurance & 0.007 & 0.081 \\
\hline it & 0.107 & 0.309 \\
\hline machin & 0.057 & 0.231 \\
\hline media & 0.004 & 0.065 \\
\hline metal & 0.026 & 0.158 \\
\hline mining & 0.002 & 0.049 \\
\hline service & 0.013 & 0.112 \\
\hline good & 0.004 & 0.06 \\
\hline nfretail & 0.003 & 0.056 \\
\hline oil & 0.018 & 0.133 \\
\hline orga & 0.01 & 0.098 \\
\hline paper & 0.008 & 0.09 \\
\hline plastic & 0.018 & 0.132 \\
\hline printing & 0.003 & 0.053 \\
\hline public & 0.047 & 0.211 \\
\hline realestate & 0.005 & 0.074 \\
\hline meal & 0.001 & 0.029 \\
\hline ship & 0.007 & 0.084 \\
\hline soap & 0.02 & 0.141 \\
\hline steel & 0.024 & 0.152 \\
\hline telecom & 0.018 & 0.133 \\
\hline textile & 0.007 & 0.081 \\
\hline transp & 0.016 & 0.126 \\
\hline utilities & 0.007 & 0.085 \\
\hline wholesale & 0.035 & 0.184 \\
\hline
\end{tabular}


Table 12

Summary Statistics on Capital per Employee in the 2010 Survey across Sectors

\begin{tabular}{|c|c|c|c|c|c|}
\hline sector & mean & sd & p10 & p50 & p90 \\
\hline aero & 52.04 & 507.03 & 0.15 & 2.00 & 60.00 \\
\hline agriculture & 63.52 & 144.43 & 0.30 & 2.00 & 200.00 \\
\hline air & 50.80 & 82.18 & 0.70 & 14.00 & 150.00 \\
\hline alcohol & 31.70 & 59.80 & 0.20 & 7.50 & 100.00 \\
\hline auto & 42.48 & 136.03 & 0.30 & 3.00 & 100.00 \\
\hline carsale & 10.40 & 14.43 & 0.10 & 2.75 & 40.00 \\
\hline cement & 357.73 & 1628.49 & 0.65 & 5.25 & 130.00 \\
\hline chemicals & 41.95 & 134.67 & 0.15 & 5.00 & 78.00 \\
\hline construction & 22.30 & 66.99 & 0.60 & 5.05 & 50.00 \\
\hline consulting & 27.20 & 252.10 & 0.10 & 0.95 & 14.00 \\
\hline drugs & 37.32 & 85.11 & 0.20 & 4.00 & 100.00 \\
\hline education & 6.01 & 26.71 & 0.03 & 0.50 & 8.00 \\
\hline elec equip & 49.78 & 213.82 & 0.15 & 3.00 & 100.00 \\
\hline electricity & 128.89 & 1214.63 & 0.30 & 3.00 & 57.40 \\
\hline electronic & 16.53 & 51.00 & 0.24 & 2.00 & 40.00 \\
\hline engineering & 16.82 & 145.79 & 0.09 & 1.00 & 20.00 \\
\hline finance & 355.64 & 3777.70 & 0.45 & 7.50 & 95.00 \\
\hline food & 38.08 & 163.44 & 0.12 & 4.00 & 70.00 \\
\hline food retail & 7.82 & 12.26 & 0.02 & 2.10 & 33.00 \\
\hline furniture & 5.48 & 7.51 & 0.10 & 1.90 & 17.00 \\
\hline glass & 28.68 & 53.99 & 0.02 & 2.00 & 120.00 \\
\hline health & 4.40 & 7.61 & 0.25 & 2.00 & 10.00 \\
\hline holding & 112.85 & 508.63 & 0.30 & 5.00 & 165.00 \\
\hline insurance & 186.45 & 709.58 & 0.20 & 2.67 & 100.00 \\
\hline it & 6.17 & 17.56 & 0.15 & 1.20 & 13.00 \\
\hline machinery & 31.90 & 136.07 & 0.20 & 3.00 & 60.00 \\
\hline media & 10.57 & 54.30 & 0.30 & 2.00 & 11.00 \\
\hline metal & 22.84 & 121.21 & 0.20 & 4.00 & 45.00 \\
\hline mining & 631.51 & 4069.59 & 0.54 & 15.00 & 600.00 \\
\hline misc. bus. servi & 24.17 & 73.68 & 0.10 & 2.00 & 60.00 \\
\hline misc. cons. good & 3.89 & 5.74 & 0.10 & 2.00 & 10.20 \\
\hline non food retail & 49.95 & 159.30 & 0.06 & 1.70 & 150.00 \\
\hline oil & 32.37 & 89.72 & 0.20 & 3.50 & 60.00 \\
\hline organization & 2.38 & 6.27 & 0.07 & 0.44 & 6.00 \\
\hline paper & 12.43 & 16.51 & 0.30 & 4.00 & 40.00 \\
\hline plastic & 31.13 & 79.83 & 0.15 & 4.00 & 70.00 \\
\hline printing & 14.10 & 22.28 & 0.15 & 1.20 & 60.00 \\
\hline public & 21.89 & 77.54 & 0.15 & 2.00 & 32.00 \\
\hline realestate & 36.77 & 87.38 & 0.30 & 6.00 & 75.00 \\
\hline restaurant & 10.13 & 13.79 & 0.10 & 2.00 & 30.00 \\
\hline ship & rail & 27.82 & 93.25 & 0.20 & 2.00 \\
\hline \multicolumn{6}{|l|}{50.00} \\
\hline soap & 44.44 & 204.84 & 0.25 & 3.50 & 92.00 \\
\hline steel & 45.22 & 217.46 & 0.18 & 3.00 & 70.00 \\
\hline telecom & 106.22 & 664.54 & 0.20 & 5.00 & 100.00 \\
\hline textile & 14.83 & 25.45 & 0.10 & 2.90 & 50.00 \\
\hline transport & 31.89 & 99.62 & 0.10 & 3.50 & 60.00 \\
\hline utilities & 22.05 & 65.51 & 0.20 & 5.00 & 25.00 \\
\hline wholesale & 18.74 & 49.99 & 0.30 & 3.50 & 50.00 \\
\hline Total & 53.91 & 870.75 & 0.15 & 2.50 & 50.00 \\
\hline
\end{tabular}




\section{B Selection Bias}

In order to assess the selection bias, I first compare the population of respondents in the CNISF survey with the population of engineers in the French Employment Survey, for which the sample is randomly selected. As engineers are identified in the French Employment Survey only from 2003, I compare the sample using data from 2003 to 2005. The samples gather respectively 10,292 individuals in the French Employment Survey and 45,994 in the CNISF survey.

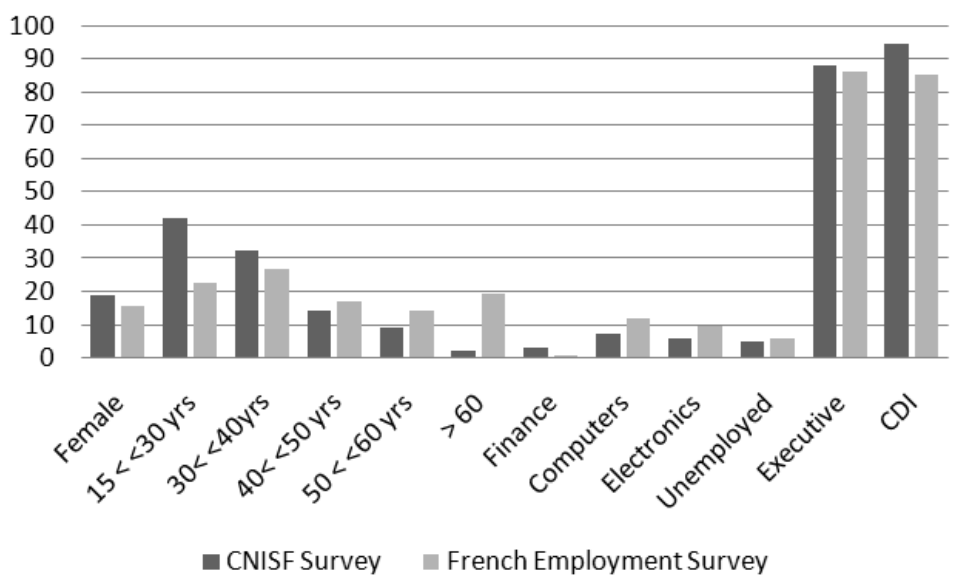

Figure 20

Comparative statistics between the French Employment and the CNISF surveys (2002 - 2005)

Frequences are reported on the vertical axis. For example, $19 \%$ of engineers are women in the CNISF survey, whereas they are nearly $15 \%$ in the French Employment one.

I find that engineers in the CNISF survey are more likely to work in finance, younger and more on permanent employment contracts.

Second, I use Towers Perrin's survey on newly graduated French engineers (2009). Towers Perrin is a leading compensation consulting company. Based on a survey among 79 French and foreign companies that have hired on average 500 French newly graduated in 2009, they compute the median gross wage, including bonuses, of three year experienced engineers. I compare it to the median gross wage including bonuses of the corresponding engineer population in the CNISF survey. I consider engineers working in the private sector, in companies with more than 2000 employees (more likely to be surveyed by Towers Perrin) and with three years of experience. Figure 2 displays the results. I find that there is a downward but negligible bias in the CNISF survey. 


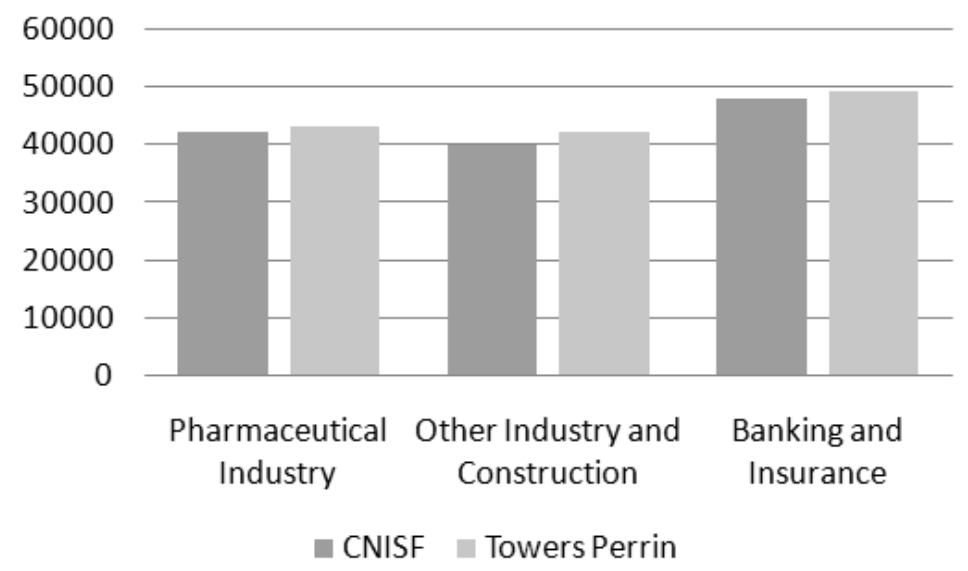

Figure 21

Total gross wage including bonuses of three year experienced engineers in Towers Perrin and CNISF's surveys, in euros

To conclude, there exists a selection bias in the CNISF survey. However, when controlling for observable variables such as age, experience and sex this bias is minimized.

\section{Sectors}

We use five digit 2008, four digit 2003 and 1993 NAF codes and 1973 NAP codes to assign engineers to 48 industries. NAF (NAP) classification is the French official industry classification, equivalent to the two-digits SIC code. The following table gives the industry names and codes. 


\begin{tabular}{|c|c|c|c|c|}
\hline & & 2008 NAF & 2003 NAF & SIC \\
\hline 1 Aero & $\begin{array}{l}\text { Aircraft } \\
\text { Aircraft Maintenance and Repair }\end{array}$ & $\begin{array}{l}30302 \\
33162\end{array}$ & $353 \mathrm{~A}, 353 \mathrm{~B}, 353 \mathrm{C}$ & 372 \\
\hline & & 0111-0116Z, 01192, 0121-0129Z, 0130Z, 0141. & & \\
\hline 2 Agriculture & Crops and Livestock Production & 0147z, 0149Z, 0150Z, 0161-0164Z, $0170 z$ & $011 \mathrm{~A}-\mathrm{G}, 012 \mathrm{~A}-J, 0132,014 \mathrm{~A}-\mathrm{Z}$ & $01,02,07$ \\
\hline & Forestry & 0210z, 0220Z, 0230Z, $0240 z$ & 020A, 020B, 0200 & 08 \\
\hline & Fishing & $03112,0312 Z, 0321 Z, 0322 z$ & $050 \mathrm{~A}, 050 \mathrm{C}$ & 09 \\
\hline 3 Air Transportation & Aircraft Rental & $\begin{array}{l}51102,51212 \\
7735 z\end{array}$ & $\begin{array}{l}6212,6222 \\
712 E\end{array}$ & $451,452,458$ \\
\hline 4 Alcoholic Beverage & & $1101 Z, 1102 A, 1102 B, 1103 Z, 11 B 04 Z, 1105 Z$ & $159 \mathrm{~A}-\mathrm{Q}$ & $2080,2082,2083,2084,2085$ \\
\hline & Wine growing & 01212 & 0116 & \\
\hline 5 Automobile and Trucks & Motor vehicles & $2910 z$ & $3412,342 B$ & 371,379 \\
\hline & Car bodies & $2920 z$ & $342 \mathrm{~A}$ & \\
\hline & Motocycles & 30912 & $354 \mathrm{~A}$ & \\
\hline & Motor Vehicles Equipment & 29312, $2932 z$ & 3432 & \\
\hline 6 Car Sales Services and Rental & Car Sales & & $4552,5012,502 z$ & $551,552,553,559$ \\
\hline & Car Rental & & 711A, 711B, 712A & 751 \\
\hline Cement, Concrete and Stone & & & & $321,322,323,324,325,326$, \\
\hline 7 Products & & 23512-2388z & 265A-E, 266A-L, 2672, 268A-C & $327,328,329$ \\
\hline 8 Chemicals & Industrial Gaz & 20112 & $241 \mathrm{~A}$ & \\
\hline & Paints & 2012Z, 2030Z, & $241 C, 2432$ & \\
\hline & Industrial Inorganic Chems (includes nuclear) & 2013A, 2013B, 24462 & 241E, 2332 & 281 \\
\hline & Industrial Organic Chems & $2014 z$ & 2416 & 286 \\
\hline & Agricultural Chemicals & 2015z, 2020z, & 2411,2422 & 287 \\
\hline & Plastic Material and Synthetic Resin and textile & $2016 Z, 20172,20602$ & 241L, 241N, 2472 & 282 \\
\hline 9 Construction & Building Contractors, general and residential & $4110 A-D$ & $452 \mathrm{~A}-\mathrm{V}$ & 152,154 \\
\hline & Operative Builders & $4120 \mathrm{~A}, 4120 \mathrm{~B}$ & 453A-H & \\
\hline & Heavy Construction & 4211Z, 4212Z, 4213A, 4213B, 42212, 42222Z, & & 161,162 \\
\hline & & 43112, 4312A-B, 4313Z, 4321A-B, 4322A-B, & & \\
\hline & $\begin{array}{l}\text { Special Construction } \\
\text { Equipment Rental for construction }\end{array}$ & $\begin{array}{l}\text { 4329A-B, 4331Z, 4332A-C, 4333Z, 4334Z, 4339Z, } \\
7732 Z\end{array}$ & $454 A-M, 451 A-D$ & $171-179$ \\
\hline 10 Consulting & Management Consulting & 70222 & $741 \mathrm{G}$ & 874 \\
\hline & Accounting & 69202 & $741 \mathrm{~A}$ & 872 \\
\hline & Market study & 73202 & $741 \mathrm{C}$ & 873 \\
\hline & Law & $6910 z$ & $741 \mathrm{E}$ & 811 \\
\hline & Advertising Consulting & 73112 & $744 \mathrm{~B}$ & 731 \\
\hline & Public Relation & 70212 & & \\
\hline 11 Drugs & $\begin{array}{l}\text { Pharmaceutical Preparations } \\
\text { Drugs }\end{array}$ & $\begin{array}{l}2110 z \\
2120 z\end{array}$ & $\begin{array}{l}244 \mathrm{~A} \\
244 \mathrm{C}, 244 \mathrm{D}\end{array}$ & 283 \\
\hline 12 Education Services & Primary Education & $85102,8520 z$ & 8012 & $820-829$ \\
\hline & Secondary Education & $85312,85322,85412$ & $802 A, 802 B$ & \\
\hline & Higher Education & 85422 & $803 z$ & \\
\hline & Other & $8559 \mathrm{~A}, 8559 \mathrm{~B}$ & & \\
\hline 13 Electric Equipment & Motors & 27112,27122 & $311 \mathrm{~A}-\mathrm{C}, 312 \mathrm{~A}-\mathrm{B}$ & \\
\hline & Storage Batteries & 27202 & $314 z$ & 362 \\
\hline & Electric Wires & $27312,2732 Z, 27332$ & 3132 & 361 \\
\hline & Lighting Equipment & $2740 z$ & $315 \mathrm{~A}-\mathrm{C}$ & 364 \\
\hline & Electrical Appliances & 27512,27522 & $297 \mathrm{~A}$ & \\
\hline & Other Electrical Equipment & $2790 z$ & $316 A-D$ & 369 \\
\hline & Electrical Equipement Repair & 33142 & & \\
\hline 14 Electricity and Gas & Electric Production & 35112 & $401 \mathrm{~A}$ & 491 \\
\hline & Electric Distribution & 35122,35132 & $401 \mathrm{C}, 401 \mathrm{E}$ & \\
\hline & Gas Production & 35212 & $402 \mathrm{~A}$ & 492 \\
\hline & Gas Distribution & 35222,35232 & $402 \mathrm{C}$ & 493 \\
\hline & Steam Supply & 35302 & 4032 & 496 \\
\hline 15 Electronic Equipment & Chips & $26112-2612 z$ & $321 \mathrm{~A}, 321 \mathrm{C}, 321 \mathrm{D}$ & 367 \\
\hline & Computers & $2620 z$ & $300 \mathrm{~A}-300 \mathrm{C}$ & 357 \\
\hline & Communication Equipment & 26302 & $322 A, 322 B, 3232$ & 366 \\
\hline & Eectronic Goods & $2640 z$ & 332A-B, 3332 & 365,363 \\
\hline & Measuring Systems & $2651 A-B, 26522$ & 3352 & 381,382 \\
\hline & Lab Analytical Instruments & 26602 & $331 \mathrm{~A}, 331 \mathrm{~B}$ & 384 \\
\hline & Optical Instruments & $2670 z-2680 z$ & $334 \mathrm{~A}-\mathrm{B}$ & 385 \\
\hline & Electronic Industry Services & $3313 Z, 3320 C, 3320 D$ & & \\
\hline 16 Engineering & Engineering & $7112 \mathrm{~A}, 7112 \mathrm{~B}$ & $742 \mathrm{~B}, 742 \mathrm{C}$ & 871 \\
\hline & Industrial Control & $7120 \mathrm{~A}, 7120 \mathrm{~B}$ & $743 \mathrm{~A}, 743 \mathrm{~B}$ & \\
\hline & $\begin{array}{l}\text { Research and Development } \\
\text { Scientific Experts }\end{array}$ & $\begin{array}{l}72112,72192 \\
7490 A, 7490 B\end{array}$ & 7312 & \\
\hline 17 Finance & Commercial Banks & 64192 & $651 \mathrm{C}, 651 \mathrm{D}, 651 \mathrm{E}, 651 \mathrm{~F}$ & 60 \\
\hline & Funds & 64302 & & \\
\hline & Credit & 64912,64922 & $652 \mathrm{~A}, 652 \mathrm{C}, 652 \mathrm{E}, 652 \mathrm{~F}$ & 61 \\
\hline & Other & 64992 & & \\
\hline & Stock Exchange & 66112 & $671 \mathrm{~A}$ & 62 \\
\hline & Portfolio Management & 66122 & $671 \mathrm{C}$ & \\
\hline & Fund Management & $6630 z$ & $671 \mathrm{E}$ & \\
\hline 18 Food Products and tobacco & Meat Products & 1011Z, 1012Z, 1013A, 1013B, 10202 & $151 \mathrm{~A}-\mathrm{F}, 152 \mathrm{Z}$ & $201-207$ \\
\hline & Canned Peserved Fruits and Veg & $1031 Z, 1032 Z, 1039 A, 1039 B$ & $153 A-F, 1522$ & \\
\hline & Fat and Oils & $1041 \mathrm{~A}, 1041 \mathrm{~B}, 10422$ & 154A-E & \\
\hline & Dairy Products & $1051 \mathrm{~A}, 1051 \mathrm{~B}, 1051 \mathrm{C}, 1051 \mathrm{D}, 10522$ & $155 \mathrm{~A}-\mathrm{F}$ & \\
\hline & Bakery Products & 1061A, 1061B, 1062Z, 1071A-D, 1072Z, 1073Z & 156A-D, 158A-F & \\
\hline & Sugar et al & $10812,10822,10832$ & $158 \mathrm{H}-\mathrm{P}$ & \\
\hline & Other Food Products & $1084 z, 1085 z, 1086 z, 1089 z, 1091 z, 1092 z$ & $158 R-V$ & 209 \\
\hline & Non alcoholic Beverage & $1107 \mathrm{~A}, 1107 \mathrm{~B}$ & 159S-T & 2086-2087 \\
\hline & Tobacco & & $160 z$ & 21 \\
\hline 19 Retail Food Trade & & $4711 \mathrm{~A}-\mathrm{F}, 4721-292$ & $521 \mathrm{~A}-\mathrm{F}$ & 54 \\
\hline 20 Furniture, Lumber & Furniture & $31012,3102 Z, 31032,3109 \mathrm{~A}, 3109 \mathrm{E}$ & $361 \mathrm{~A}-\mathrm{M}$ & 25 \\
\hline & Lumber & 1610A-B, 1621Z-29Z & $201 \mathrm{~A}-\mathrm{B}, 202 \mathrm{Z}, 203 \mathrm{Z}, 204 \mathrm{Z}, 205 \mathrm{~A}-\mathrm{C}$ & 24 \\
\hline 21 Glass Products & & $23112-23492$ & $261 A-K, 262 A-L, 264 A-C, 263 Z$ & $321,322,323$ \\
\hline 22 Healthcare & Health Services & 8610Z-8690E & $851 \mathrm{~A}-\mathrm{L}$ & 80 \\
\hline & Nursing and Social Home & 8710A-8790B & 853A-E & \\
\hline & Social Services & 8810A-8899B & $853 \mathrm{G}-\mathrm{k}$ & 83 \\
\hline 23 Holding Management Activities & & $741 \mathrm{~J}$ & $64202,7010 z$ & 67 \\
\hline 24 Insurance & Life Insurance & 65112 & $660 \mathrm{~A}$ & 63 \\
\hline & Other Insurance & 65122 & $660 E, 660 G$ & 64 \\
\hline & Reinsurance & 65202 & $660 \mathrm{~F}$ & \\
\hline & Insurance agents & 66222 & & \\
\hline & Evaluation & 66212 & & \\
\hline & Relative Services & 66292 & 6722 & \\
\hline
\end{tabular}




\begin{tabular}{|c|c|c|c|c|}
\hline \multicolumn{5}{|l|}{ Information Technology } \\
\hline \multirow[t]{8}{*}{25 Services } & Computer Programming & 62012 & $722 \mathrm{~A}-\mathrm{C}$ & 737 \\
\hline & Computer Consulting & $6202 \mathrm{~A}-\mathrm{B}$ & 7212 & \\
\hline & Computer Maintenance and Repair & 62032 & 7252 & \\
\hline & Other Computer Related Services & $6209 z$ & 7262 & \\
\hline & Data Processing & 63112 & $723 z, 724 z$ & \\
\hline & Computer rental & 77332 & & \\
\hline & Internet Services & 63122 & & \\
\hline & Information Related Services & 63992 & & \\
\hline \multirow[t]{2}{*}{26 Machinery } & & 28112-2899B & 291A-300A & $351-356$ \\
\hline & Machin Industry Services & $33122,3320 \mathrm{~A}, 3320 \mathrm{~B}$ & & 359 \\
\hline 27 Entertainment and media & Publishing & 5811-21Z, 5821Z, 5829A-C & $221 \mathrm{~A}-\mathrm{E}$ & \\
\hline & Motion Picture & $5911 \mathrm{~A}-5914 \mathrm{Z}$ & 921AGJ & 78 \\
\hline & Music & $5920 z$ & 2216 & 79 \\
\hline & Advertising Agency & 73122 & $744 \mathrm{~A}$ & 731 \\
\hline & Radio-TV Broadcaster & $6010 Z, 6020 A-B$ & 922A-F & 483,484 \\
\hline & Theatre & $90012-9004 z$ & $923 \mathrm{~A}-\mathrm{K}$ & \\
\hline 28 Metal Products & & $25212-2599 B$ & $281 A, 281 C, 282 C-287 Q$ & 34 \\
\hline & Metal products repair and maintenance & 33112 & & \\
\hline 29 Mining & Metal Mining & $0710 z, 0721 z, 07292$ & $120 z, 1312,132 z$ & 10 \\
\hline & Non Metalic Minerals & $0811 z, 0812 z, 08912,0892 z, 0893 z, 0899 z$ & 141A-E, 142A-C, 143Z, 1442 & 14 \\
\hline & 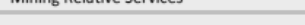 & 09102,09002 & & \\
\hline 30 Miscellanous Business Services & Business Services & & $82748 A-K$ & $733,734,738$ \\
\hline & Cleaning and Maintenance & & 817472 & \\
\hline & Security and investigation & & 807462 & \\
\hline & Job Agency & & $78745 \mathrm{~A}, \mathrm{~B}$ & \\
\hline Miscellanous Industry and & & & & \\
\hline 31 Cosumer Goods & Money & 32112 & $362 A$ & 39 \\
\hline & Jewelry & 32122 & $362 \mathrm{C}, 366 \mathrm{~A}$ & \\
\hline & Musical Instruments & $3220 z$ & 3632 & \\
\hline & Toys & 32402 & $365 z$ & \\
\hline & Sport Equipement & 32302 & $364 z$ & \\
\hline & Medical Equipement & $3250 \mathrm{~A}, 3250 \mathrm{~B}$ & & \\
\hline & Other & 32912,32992 & $366 \mathrm{C}, \mathrm{E}$ & \\
\hline 32 Non Food Retail Trade & & $4719 \mathrm{~A}-\mathrm{B}, 4741-43 Z, 47512-47998$ & $522 \mathrm{~A}-\mathrm{P}, 523 \mathrm{~A}-526 \mathrm{H}$ & $53,56,57$ \\
\hline 33 Oil & Oil Extraction & $0610 z$ & 1112 & 14 \\
\hline & Oil Field Services & $0910 z$ & $112 z$ & \\
\hline & Petroleum Refining & $1920 z$ & 2322 & 29 \\
\hline & Coking & $1910 z$ & 2312 & \\
\hline 34 Membership Organization & & & & 86 \\
\hline 35 Paper and Paperboard Mills & & $211 A-C, 212 A-L$ & & 26 \\
\hline 36 Plastic and Rubber Products & Rubber Products & 22112,22192 & $251 \mathrm{~A}-\mathrm{E}$ & 30 \\
\hline & Plastic Products & $2221 Z, 22222,22232$ & $252 \mathrm{~A}-\mathrm{C}$ & \\
\hline & Misc Plastic Products & $2229 A, 2229 B$ & $252 \mathrm{G}-\mathrm{H}$ & \\
\hline 37 Printing & & $18112,18122,18132,18142,18202$ & $221 \mathrm{~A}-J, 222 \mathrm{~A}-\mathrm{G}, 223 \mathrm{~A}-\mathrm{E}$ & 27 \\
\hline 38 Public Administriation & General Public Administration & $84112,84122,84132$ & $751 \mathrm{~A}-\mathrm{G}$ & \\
\hline & Specific Administrations & $84212-8425 z$ & $752 \mathrm{~A}-\mathrm{J}$ & \\
\hline & Welfare & $8430 \mathrm{~A}-\mathrm{C}$ & $753 \mathrm{~A}-\mathrm{C}$ & \\
\hline & Cultural Activities & $91012-9104 z$ & 925A, 925C, 925E, 926A & \\
\hline 39 Real Estate & Real Estate Operators & $68102,6820 \mathrm{~A}, 6820 \mathrm{~B}$ & 701A-F, 702A-C & 65 \\
\hline & Real Estate Agents and Managers & $68312,6832 \mathrm{~A}, 6832 \mathrm{~B}$ & $703 \mathrm{~A}-\mathrm{D}$ & \\
\hline 40 Hotel and eating places & Hotels & $55102-55902$ & $551 \mathrm{~A}, 552 \mathrm{~F}$ & 70 \\
\hline & Eating and Drinking places & 5610A-5630Z & $553 \mathrm{~A}-602 \mathrm{~B}$ & 58 \\
\hline $\begin{array}{l}\text { Ship Building, Railroad } \\
\text { Equipment and ot transp }\end{array}$ & & & & \\
\hline 41 equipment & Shipbuilding and repair & $30112,3012 z$ & 351B-C-E & 373 \\
\hline & Railroad Equipment & 30202 & 3522 & 374 \\
\hline & Tanks & $3040 z$ & $351 \mathrm{~A}$ & 376 \\
\hline & Bicycles & 30922 & $354 \mathrm{C}$ & 375 \\
\hline & Repair & 33152,33172 & & \\
\hline & Other & $3099 \mathrm{z}$ & $354 E-2$ & 379 \\
\hline 42 Parachemicals, Cosmetics & Soap and other detergents & 20412 & $245 \mathrm{~A}$ & 284 \\
\hline & Perfumes and Cosmetics & 20422 & $245 \mathrm{C}$ & \\
\hline & Paints & 20302 & 2432 & 285 \\
\hline & Other Chemical Products & $2051 Z, 2052 Z, 2053 Z, 2059 z$ & $246 \mathrm{~L}$ & \\
\hline 43 Steel Works etc & Primary Metal Industry & $24102,2420 z$ & $271 Y, 2712$ & 33 \\
\hline & Steel Works & $24312-24342$ & $272 \mathrm{~A}-\mathrm{C}, 273 \mathrm{~A}-\mathrm{G}$ & \\
\hline & Non Ferrous Industry & $2442-24452$ & $274 \mathrm{C}-\mathrm{M}$ & \\
\hline & Foundries & $2451 z-2454 z$ & $275 \mathrm{~A}-\mathrm{G}$ & \\
\hline 44 Telecommunications and mail & $\begin{array}{l}\text { Telecommunications } \\
\text { Mail }\end{array}$ & $\begin{array}{l}6110 z, 6120 z, 6130 z, 6190 z \\
5310 z, 5320 z\end{array}$ & $\begin{array}{l}642 \mathrm{~A}, 642 \mathrm{~B}, 642 \mathrm{C} \\
641 \mathrm{~A}, 641 \mathrm{C}\end{array}$ & $481,482,489$ \\
\hline & & & 171A-P, 172A-J, 173Z, 174A-C, & \\
\hline 45 Textiles and Apparel & Textile Mill Products & $1310 z, 1320 z, 1330 Z, 13912-1396 z, 1399 z$ & $\begin{array}{l}175 A-G, 176 Z, 177 A-C, \\
181 Z, 182 A-J, 183 Z, 191 Z, 192 Z,\end{array}$ & 22 \\
\hline & Apparel and other Textile Products & 1411z-1414Z, 1419z, 1420Z, 1431Z, $1439 z$ & 1932 & 23,24 \\
\hline 46 Transportation & Railroad Passenger Transportation & 49102 & 6012 & 401 \\
\hline & Railway Freight & $4920 z$ & & \\
\hline & Bus Transp & 49312, 4939A-B & $602 A-B$ & 41 \\
\hline & Taxicabs & 49322 & $602 E, 602 G$ & \\
\hline & Road Freight & $4941 \mathrm{~A}-\mathrm{C}, 49422$ & $602 L, M, N, P$ & \\
\hline & Pipelines & $4950 z$ & 6032 & 46 \\
\hline & Water Transport & $5010 z, 5020 z, 5030 z, 5040 z$ & $601 \mathrm{~A}-\mathrm{B}, 612 \mathrm{Z}, 6212,6222$ & 44 \\
\hline & Storage & $5210 A, 5210 B$ & & \\
\hline & Related Services & 52212,52222 & & \\
\hline & Handling & 5224A-B & & \\
\hline & Freight & $5229 \mathrm{~A}$ & & 42 \\
\hline & Travel Agencies & $79112,79122,79902$ & & 47 \\
\hline 47 Utilities & Water Supply & $3600 z, 3700 z$ & $410 z$ & 494 \\
\hline & Sanitary Services & $3900 z$ & 900A-G & 495 \\
\hline 48 Wholesale & & 46 & $50-51$ & \\
\hline
\end{tabular}


D Wage Equations

D.1 With Sectoral Dummies 
Table 13

The dependant variable is the log of the yearly gross wage - Each industry has a dummy variable - Decomposition in 48 sectors

The model includes a female dummy, a married dummy, a female $\times$ married dummy, a Paris area dummy, 7 education dummies, a working abroad dummy, years of professional experience and its square, 4 hierarchic responsibility dummies, 9 occupation dummies, 4 firm size dummies, 4 firm type dummies .

\begin{tabular}{|c|c|c|c|c|c|c|}
\hline & \multicolumn{2}{|c|}{ 1986-1989 } & \multicolumn{2}{|c|}{$1995-2000$} & \multicolumn{2}{|c|}{$2005-2007$} \\
\hline Industry & Coef. & (Std. Err.) & Coef. & (Std. Err.) & Coef. & (Std. Err.) \\
\hline Aerospace & -0.003 & $(0.005)$ & -0.034 & $(0.008)$ & -0.044 & $(0.007)$ \\
\hline Agriculture & -0.146 & $(0.011)$ & -0.102 & $(0.022)$ & -0.179 & $(0.021)$ \\
\hline Air transportation & 0.062 & $(0.016)$ & 0.060 & $(0.017)$ & -0.027 & $(0.018)$ \\
\hline Alcohol & 0.037 & $(0.016)$ & -0.037 & $(0.031)$ & -0.006 & $(0.022)$ \\
\hline Auto & 0 & $(0.005)$ & 0.001 & $(0.006)$ & 0.001 & $(0.005)$ \\
\hline Carsale & 0.014 & $(0.027)$ & 0.116 & $(0.038)$ & 0 & $(0.026)$ \\
\hline Cement & -0.009 & $(0.008)$ & -0.008 & $(0.022)$ & 0.045 & $(0.019)$ \\
\hline Chemicals & 0.072 & $(0.005)$ & 0.089 & $(0.010)$ & 0.034 & $(0.007)$ \\
\hline Construction & -0.028 & $(0.004)$ & -0.044 & $(0.007)$ & -0.068 & $(0.006)$ \\
\hline Consulting & - & - & 0.162 & $(0.009)$ & 0.125 & $(0.006)$ \\
\hline Drugs & 0.05 & $(0.010)$ & 0.096 & $(0.015)$ & 0.046 & $(0.010)$ \\
\hline Education & -0.1 & $(0.021)$ & -0.193 & $(0.015)$ & -0.162 & $(0.015)$ \\
\hline Electric equipment & -0.056 & $(0.005)$ & -0.026 & $(0.008)$ & -0.033 & $(0.008)$ \\
\hline Electricity and gas & 0.036 & $(0.005)$ & 0.062 & $(0.008)$ & 0.109 & $(0.009)$ \\
\hline Electronic & -0.03 & $(0.004)$ & -0.02 & $(0.005)$ & -0.033 & $(0.005)$ \\
\hline Engineering & 0.021 & $(0.003)$ & -0.035 & $(0.005)$ & -0.04 & $(0.004)$ \\
\hline Finance & 0.070 & $(0.008)$ & 0.157 & $(0.009)$ & 0.320 & $(0.006)$ \\
\hline Food products & 0.015 & $(0.007)$ & 0.005 & $(0.011)$ & -0.022 & $(0.007)$ \\
\hline Food retail & -0.003 & $(0.027)$ & -0.148 & $(0.034)$ & -0.158 & $(0.026)$ \\
\hline Furniture & -0.097 & $(0.020)$ & -0.053 & $(0.019)$ & -0.047 & $(0.015)$ \\
\hline Glass & 0.009 & $(0.012)$ & -0.005 & $(0.018)$ & 0.012 & $(0.019)$ \\
\hline Health & -0.064 & $(0.026)$ & -0.145 & $(0.024)$ & -0.098 & $(0.026)$ \\
\hline Holding & 0.114 & $(0.018)$ & 0.111 & $(0.009)$ & 0.095 & $(0.007)$ \\
\hline Insurance & 0.02 & $(0.012)$ & 0.054 & $(0.014)$ & 0.044 & $(0.014)$ \\
\hline It & - & - & 0.013 & $(0.006)$ & 0.007 & $(0.005)$ \\
\hline Machin & -0.012 & $(0.004)$ & -0.026 & $(0.007)$ & -0.033 & $(0.006)$ \\
\hline Media & -0.052 & $(0.028)$ & -0.056 & $(0.026)$ & -0.011 & $(0.016)$ \\
\hline Metal & -0.052 & $(0.006)$ & -0.052 & $(0.009)$ & -0.031 & $(0.009)$ \\
\hline Mining & 0.137 & $(0.017)$ & 0.101 & $(0.021)$ & 0.049 & $(0.031)$ \\
\hline Misc. services & -0.017 & $(0.017)$ & 0.04 & $(0.015)$ & 0.027 & $(0.011)$ \\
\hline Misc. goods & 0.021 & $(0.011)$ & -0.023 & $(0.043)$ & 0.024 & $(0.027)$ \\
\hline Non food retail & -0.013 & $(0.018)$ & 0.001 & $(0.028)$ & -0.049 & $(0.020)$ \\
\hline Oil & 0.168 & $(0.006)$ & 0.119 & $(0.011)$ & 0.138 & $(0.013)$ \\
\hline Organizations & - & - & -0.138 & $(0.014)$ & -0.056 & $(0.015)$ \\
\hline Paper & 0.073 & $(0.010)$ & 0.099 & $(0.013)$ & 0.069 & $(0.016)$ \\
\hline Plastic and rubber & 0.001 & $(0.007)$ & 0.015 & $(0.009)$ & 0.015 & $(0.009)$ \\
\hline Printing & -0.022 & $(0.016)$ & -0.045 & $(0.028)$ & -0.023 & $(0.024)$ \\
\hline Public adminsitration & -0.095 & $(0.005)$ & -0.111 & $(0.011)$ & -0.057 & $(0.015)$ \\
\hline Realestate & 0.01 & $(0.012)$ & 0.022 & $(0.020)$ & 0.056 & $(0.017)$ \\
\hline Restaurant and hotel & -0.053 & $(0.034)$ & -0.031 & $(0.038)$ & -0.091 & $(0.037)$ \\
\hline Ship building & 0.011 & $(0.016)$ & -0.015 & $(0.022)$ & -0.014 & $(0.015)$ \\
\hline Soap and cosmetics & 0.014 & $(0.007)$ & 0.028 & $(0.011)$ & 0.023 & $(0.010)$ \\
\hline Steel & 0.042 & $(0.005)$ & 0.017 & $(0.009)$ & 0.024 & $(0.011)$ \\
\hline Telecom & -0.079 & $(0.010)$ & 0.041 & $(0.009)$ & 0.028 & $(0.008)$ \\
\hline Textile & -0.033 & $(0.010)$ & -0.034 & $(0.015)$ & -0.018 & $(0.016)$ \\
\hline Transportation & -0.005 & $(0.007)$ & 0.01 & $(0.010)$ & -0.005 & $(0.011)$ \\
\hline Utilities & 0.009 & $(0.012)$ & -0.041 & $(0.015)$ & -0.071 & $(0.012)$ \\
\hline Wholesale & 0.008 & $(0.006)$ & 0.049 & $(0.007)$ & 0.034 & $(0.006)$ \\
\hline $\mathrm{N}$ & & 42,619 & & 35,792 & & 52,098 \\
\hline
\end{tabular}


D.2 Without Sectoral Dummies 
Table 14

The dependant variable is the log of the yearly gross wage

\begin{tabular}{lcc}
\hline \multicolumn{1}{c}{ Variable } & Coefficient & (Std. Err.) \\
\hline sx & -0.059 & $(0.003)$ \\
cpl & 0.045 & $(0.001)$ \\
wife & -0.038 & $(0.003)$ \\
paris & 0.121 & $(0.001)$ \\
foreign & 0.322 & $(0.002)$ \\
experience & 0.051 & $(0.000)$ \\
exp2 & -0.001 & $(0.000)$ \\
seniority & 0.000 & $(0.000)$ \\
gr & 0.115 & $(0.002)$ \\
Iresp_1 & 0.081 & $(0.001)$ \\
Iresp_2 & 0.215 & $(0.002)$ \\
Iresp_3 & 0.374 & $(0.003)$ \\
Iact_2 & -0.023 & $(0.002)$ \\
Iactd_3 & -0.010 & $(0.002)$ \\
Iactd_4 & 0.059 & $(0.002)$ \\
Iactd_5 & 0.106 & $(0.003)$ \\
Iactd_6 & 0.136 & $(0.003)$ \\
Iactd_7 & -0.130 & $(0.005)$ \\
Iactd_8 & 0.057 & $(0.003)$ \\
Iact__9 & -0.018 & $(0.002)$ \\
Inaten_2 & 0.060 & $(0.003)$ \\
Inaten_3 & 0.009 & $(0.004)$ \\
Inaten_4 & -0.184 & $(0.004)$ \\
Inaten_5 & -0.076 & $(0.007)$ \\
Isize_2 & 0.095 & $(0.002)$ \\
Isize_3 & 0.146 & $(0.002)$ \\
Isize_4 & 0.184 & $(0.002)$ \\
Iyear_1986 & 0.160 & $(0.003)$ \\
Iyear_1989 & 0.272 & $(0.003)$ \\
Iyear_1992 & 0.365 & $(0.003)$ \\
Iyear_1995 & 0.453 & $(0.003)$ \\
Iyear_1998 & 0.396 & $(0.003)$ \\
Iyear_2000 & 0.453 & $(0.003)$ \\
Iyear_2004 & 0.527 & $(0.003)$ \\
Iyear_2005 & 0.507 & $(0.003)$ \\
Iyear_2006 & 0.509 & $(0.003)$ \\
Iyear_2007 & 0.522 & $(0.003)$ \\
Iyear_2008 & 0.571 & $(0.003)$ \\
Intercept & 9.523 & $(0.004)$ \\
\hline & & \\
\hline N & & 235117 \\
R 2 & & \\
F (38,235078) & 14247.026 \\
\hline
\end{tabular}




\section{E Quantile Regressions}

Table 15

The dependant variable is the log of the yearly gross wage - Each industry has a dummy variable - Decomposition in 48 sectors - 2005-2007

The model includes a female dummy, a married dummy, a female $\times$ married dummy, a Paris area dummy, 7 education dummies, a working abroad dummy, years of professional experience and its square, 4 hierarchic responsibility dummies, 9 occupation dummies, 4 firm size dummies, 4 firm type dummies

\begin{tabular}{|c|c|c|c|c|c|c|}
\hline \multirow[b]{2}{*}{ Industry } & \multicolumn{2}{|c|}{ 10th percentile } & \multicolumn{2}{|c|}{ 50th percentile } & \multicolumn{2}{|c|}{ 90th percentile } \\
\hline & Coef. & (Std. Err.) & Coef. & (Std. Err.) & Coef. & (Std. Err.) \\
\hline Aerospace & 0.042 & $(0.015)$ & -0.027 & $(0.011)$ & -0.082 & $(0.018)$ \\
\hline Agriculture & -0.124 & $(0.03)$ & -0.16 & $(0.021)$ & -0.12 & $(0.035)$ \\
\hline Air transportation & -0.019 & $(0.026)$ & -0.035 & $(0.019)$ & 0.048 & $(0.030)$ \\
\hline Alcohol & 0.029 & $(0.03)$ & -0.005 & $(0.022)$ & 0.004 & $(0.034)$ \\
\hline Auto & 0.082 & $(0.015)$ & 0.021 & $(0.01)$ & -0.031 & $(0.017)$ \\
\hline Carsale & 0.021 & $(0.034)$ & -0.013 & $(0.025)$ & 0.023 & $(0.040)$ \\
\hline Cement & 0.039 & $(0.028)$ & 0.056 & $(0.02)$ & 0.078 & $(0.032)$ \\
\hline Chemicals & 0.079 & $(0.016)$ & 0.066 & $(0.011)$ & 0.011 & $(0.019)$ \\
\hline Construction & -0.036 & $(0.015)$ & -0.047 & $(0.011)$ & -0.056 & $(0.018)$ \\
\hline Consulting & 0.04 & $(0.015)$ & 0.096 & $(0.011)$ & 0.276 & $(0.018)$ \\
\hline Drugs & 0.073 & $(0.018)$ & 0.049 & $(0.013)$ & 0.044 & $(0.021)$ \\
\hline Education & -0.177 & $(0.025)$ & -0.171 & $(0.017)$ & -0.134 & $(0.029)$ \\
\hline Electric equipment & 0.025 & $(0.016)$ & -0.024 & $(0.012)$ & -0.049 & $(0.019)$ \\
\hline Electricity and gas & 0.128 & $(0.016)$ & 0.112 & $(0.012)$ & 0.13 & $(0.018)$ \\
\hline Electronic & 0.022 & $(0.014)$ & -0.017 & $(0.01)$ & -0.055 & $(0.017)$ \\
\hline Engineering & -0.019 & $(0.014)$ & -0.034 & $(0.01)$ & -0.038 & $(0.016)$ \\
\hline Finance & 0.092 & $(0.016)$ & 0.204 & $(0.011)$ & 0.816 & $(0.018)$ \\
\hline Food products & -0.023 & $(0.016)$ & -0.014 & $(0.011)$ & -0.004 & $(0.019)$ \\
\hline Food retail & -0.217 & $(0.036)$ & -0.163 & $(0.026)$ & -0.121 & $(0.041)$ \\
\hline Furniture & 0.006 & $(0.023)$ & -0.043 & $(0.016)$ & -0.067 & $(0.026)$ \\
\hline Glass & 0.044 & $(0.027)$ & 0.033 & $(0.019)$ & -0.026 & $(0.031)$ \\
\hline Health & -0.149 & $(0.035)$ & -0.1 & $(0.025)$ & -0.053 & $(0.041)$ \\
\hline Holding & 0.061 & $(0.016)$ & 0.081 & $(0.011)$ & 0.149 & $(0.018)$ \\
\hline Insurance & 0.007 & $(0.022)$ & 0.043 & $(0.016)$ & 0.113 & $(0.026)$ \\
\hline It & -0.036 & $(0.014)$ & -0.012 & $(0.01)$ & 0.047 & $(0.017)$ \\
\hline Machin & 0.024 & $(0.015)$ & -0.019 & $(0.011)$ & -0.05 & $(0.018)$ \\
\hline Media & -0.011 & $(0.023)$ & 0.004 & $(0.017)$ & 0.037 & $(0.027)$ \\
\hline Metal & -0.023 & $(0.017)$ & -0.012 & $(0.012)$ & -0.038 & $(0.020)$ \\
\hline Mining & 0.072 & $(0.04)$ & 0.024 & $(0.03)$ & 0.076 & $(0.046)$ \\
\hline Misc. services & -0.025 & $(0.019)$ & 0.04 & $(0.014)$ & 0.088 & $(0.022)$ \\
\hline Misc. goods & 0.015 & $(0.035)$ & 0.035 & $(0.026)$ & -0.009 & $(0.039)$ \\
\hline Non food retail & -0.144 & $(0.028)$ & 0.011 & $(0.02)$ & 0.004 & $(0.032)$ \\
\hline Oil & 0.201 & $(0.021)$ & 0.158 & $(0.015)$ & 0.113 & $(0.024)$ \\
\hline Organizations & -0.045 & $(0.024)$ & -0.089 & $(0.016)$ & -0.091 & $(0.026)$ \\
\hline Paper & 0.102 & $(0.024)$ & 0.059 & $(0.017)$ & 0.048 & $(0.028)$ \\
\hline Plastic and rubber & 0.065 & $(0.017)$ & 0.02 & $(0.012)$ & -0.012 & $(0.020)$ \\
\hline Printing & -0.04 & $(0.033)$ & -0.057 & $(0.024)$ & -0.014 & $(0.038)$ \\
\hline Public adminsitration & -0.048 & $(0.024)$ & -0.057 & $(0.016)$ & -0.021 & $(0.026)$ \\
\hline Realestate & 0.042 & $(0.025)$ & 0.054 & $(0.018)$ & 0.085 & $(0.028)$ \\
\hline Restaurant and hotel & -0.098 & $(0.046)$ & -0.03 & $(0.035)$ & -0.051 & $(0.054)$ \\
\hline Ship building & 0.036 & $(0.023)$ & -0.006 & $(0.016)$ & -0.019 & $(0.026)$ \\
\hline Soap and cosmetics & 0.046 & $(0.018)$ & 0.017 & $(0.013)$ & 0.007 & $(0.021)$ \\
\hline Steel & 0.084 & $(0.019)$ & 0.042 & $(0.013)$ & 0.018 & $(0.022)$ \\
\hline Telecom & 0.027 & $(0.016)$ & 0.034 & $(0.011)$ & 0.044 & $(0.018)$ \\
\hline Textile & -0.016 & $(0.024)$ & -0.021 & $(0.017)$ & -0.018 & $(0.028)$ \\
\hline Utilities & -0.062 & $(0.02)$ & -0.065 & $(0.014)$ & -0.07 & $(0.023)$ \\
\hline Wholesale & -0.004 & $(0.015)$ & 510.035 & $(0.011)$ & 0.071 & $(0.018)$ \\
\hline Transport (ref) & -0.02 & (ref) & -0.017 & (ref) & -0.047 & (ref) \\
\hline $\mathrm{N}$ & & 59062 & & 32888 & & 48731 \\
\hline
\end{tabular}




\section{F The survey}

I Signalétique personnelle

Code CNISF (ne rien inscrire)

Codes pour le WISF

1. Êtes-vous membre de l'association des anciens élèves de votre école ?

1 Oui 2 Non 3 Il n'en existe pas

mass

2. Année de naissance: $19 ـ$

3. Sexe: 1 Homme 2 Femme

4. Utilisez-vous un e-mail ?

1 Oui, personnel

2 Oui, au bureau

3 0ui, aux deux

Si la prochaine enquête se faisait à l'aide d'internet, y participeriez-vous ? $\quad 1$ Oui $\quad 2$ Non

4 Non

Si la prochaine enquête se faisait à l'aide d'internet, y participeriez-vous ? $\quad 1$ 0ui $\quad 2$ Non

\section{Formation d'ingénieur}

5. Votre diplôme d'ingénieur a-t-il été obtenu par :

1 Formation initiale (de base) 2 Apprentissage

$\left.{ }^{\star}{ }^{*}\right)$ Si réponse 3 : Depuis combien d'années travailliez-vous quand vous avez entrepris ce diplôme ?

FORM ANFC

6. Votre formation à l'entrée en école d'ingénieur :

1 Bac (prépas intégrées) 2 Classes préparatoires

$3 \mathrm{BaC}+2$ ou 3 (DUT, BTS, Licence) 4 Bac +4 (Maitrise) ou plus 5 Autre

FOPR

7. Diplôme d'ingénieur :

Première école : Sigle Ville

Année de sortie

(Ne rien inscrire
dans lo case grisée)

Deuxième école : Sigle

ville

Année de sortie

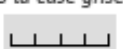

ASS1 TOMO 1

ASS2 PROMO 2

8. À l'issue de votre formation d'ingénieur, quelle était votre spécialité de sortie ? Reprenez les chiffres de la liste ci-dessous: Spécialité 1

1 Généraliste, sans spécialité dominante Spécialité 2

SPE 1

2 Agronomie, sciences de la vie, agro-alimentaire

6 Génie civil, BTP, mines, géologie

3 Chimie, génie des procédés

4 Électronique, télécommunications

7 Informatique, génie logiciel, math. appliquées

8 Mécanique, production, productique

9 Physique, matériaux

5 Électrotechnique, automatique, électricité

10 Autre

\section{L'entreprise qui vous employait au 31-12-2000}

9. Secteur d'activité :

Code APE au 31-12-2000 (ce code en 3 chiffres et une lettre figure sur vos bulletins de salaire) :

1 Agro-alimentaire, agriculture

6 Bureaux d'études techniques, ingénierie

2 Industrie, energie

7 Finance, banque, assurance

3 BTP/construction

8 Télécommunications

4 Sociétés de conseil, audit, études non techn.

9 Commerce, ditribution, transport

5 SSII, sociétés de services informatiques

10 Fonction publique : État, territoriale ou hospitalière

11 Autre

Travaillez-vous dans le secteur de la nouvelle économie (télécoms, e-business) ? $\quad 1$ 0ui $\quad 2$ Non 
10. Nature de l'entreprise au 31-12-2000

11. Taille de l'entreprise (nombre de salariés) au 31-12-2000
1 Pas de salarié
321 à 499 salariés
55000 salariés et plus
21 à 20 salariés
4500 à 4999 salaries

TAILE

12. Lieu de travail (indiquez : le numéro à 2 chiffres du département ; DOM : 97 ; TOM : 98 ; étranger : 99)

13. Pour l'étranger : indiquez le code postal international ( $D, C H, U K, U S A \ldots)$

14. S'agit-il d'une entreprise que vous avez créée ? 1 Oui Ou d'une reprise ? 2 0ui

\section{Caractéristiques de votre activité principale au 31-12-2000}

15. Situation professionnelle au 31-12-2000 (choix unique)
1 Fonctionnaire
2 Salarié en contrat à durée indéterminée
3 Salarié en contrat à durée déterminée
4 Salarie à employeurs multiples
5 Intérim, vacations ou contrat précaire
$6 \mathrm{CSN}$

\section{Travailleur indépendant}

8 Gerant ou dirigeant majoritaire

9 Contrat lie à une thèse : CIFRE, ATER...

10 Demandeur d'emploi

11 Pré-retraité ou retraité

12 Autre (étudiant, congé sans solde, service national...)

16. Temps partiel. Si cette activité est à temps partiel, indiquez-en le pourcentage :

\section{Activité dominante au 31-12-2000}

(Un seul choix : cochez la case correspondant à l'activité que vous avez evercée directement ou celle dont vous aviez la responsabilité)

1 Production, fabrication, chantiers

2 Approvisionnement, logistique, qualité, sécurité, organisation, maintenance, environnement...

3 Etudes, recherche, projets :

3.1 Recherche fondamentale

3.2 Recherche, essais, développement

3.3 Projet, ingénierie, études techniques

3.4 Conseil, audit, études non techniques

3.5 Management de projets techniques

4 Informatique, systèmes d'information, réseaux :

4.1 Exploitation, production

4.2 Études, projets et développement

4.3 Administration, maintenance, support

4.4 Technico-commercial, commercial, marketing
5 Technico-commercial, marketing, vente :

5.1 Technico-commercial (sauf informatique)

5.2 Commercial, vente, marketing (sauf informatique)

6 Administration des entreprises : finances, juridique, communication, ressources humaines...

7 Direction générale

8 Administration dans la Fonction publique

9 Enseignement, formation

10 Autre

18. Si vous êtes informaticien, est-ce dans le domaine de :
1 Informatique industrielle
3 Informatique des systèmes d'information
2 Informatique des systèmes et réseaux
4 Internet 
19. Niveau hiérarchique au 31-12-2000

1 Pas encore cadre

2 Cadre sans responsabilité hiérarchique

3 Responsable d'une équipe

4 Responsable d'un service ou d'un département
5 Directeur de fonction centrale, d'établissement, de division, de branche

6 PDG ou DG

20. Nombre de salariés sous votre responsabilité hiérarchique :

21. Si vous n'êtes pas dans la ligne hiérarchique, avez-vous un titre professionnel (expert...) conféré par votre entreprise? 1 0ui 2 Non

\section{Ressources professionnelles en 2000}

Il s'agit du revenu complet lié a l'activité que vous venez de décrire, primes et avantages en nature compris.

si vous n'avez pas travaillé a temps plein ou toute l'année, merci de calculer le revenu en équivalent année pleine.

22. Revenu professionnel brut annuel 2000 (en kF) :

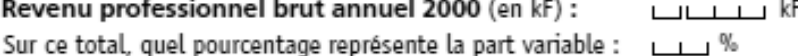

23. Bénéficiez-vous en outre de stock-options ? 1 0ui $\quad 2$ Non

24. Revenu professionnel brut annuel 1999 (pour rappel) : ــــ $\mathrm{kF}$

25. Revenu professionnel brut annuel prévisible pour 2001 (en kF) :

\section{Parcours professionnel}

26. En quelle année avez-vous commencé à travailler comme ingénieur ?

27. Nombre d'années d'ancienneté. Dans l'entreprise :

$ـ$; d dans l'activité dominante :

28. Parcours professionnel :

Indiquez vos trois derniers emplois caractérisés par une activité dominante et un niveau hiérarchique.

Nop

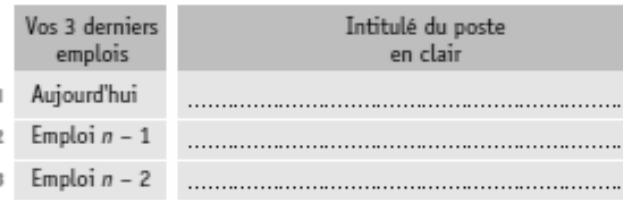

PACTD

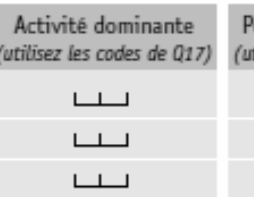

РPH

Position hiérarchique (utibisez les codes de Q19)

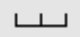

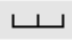

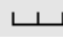

$\mathrm{PH}$

Combien d'emplois avez-vous occupés au total depuis que vous êtes ingénieur?

Dans combien d'établissements au total ?
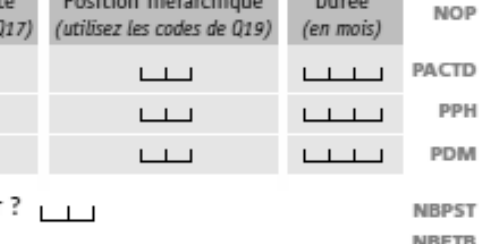

NBPST

NBETB

\section{Réduction du temps de travail (RTT)}

29. La RTT a-t-elle été mise en place dans votre entreprise ?

1 Oui 2 Non 3 Ne sait pas RTTE

30. Que comporte l'accord de RTT pour vous (plusieurs réponses possibles) :
1 Réduction quotidienne
5 Modulation, annualisation
2 Réduction par $1 / 2$ journées ou journées sur une courte durée
6 Autre modalité
3 Des jours de congés supplémentaires
7 Non concerne (cadre dirigeant)
4 Mise en place d'un Compte épargne temps
8 Autres

ART

31. Estimez-vous que, pour vous, la RTT se traduit réellement par :

1 Une réduction de votre durée hebdomadaire de travail ; $\quad 2$ Une réduction de votre nombre de jours de travail ERT

32. Êtes-vous satisfait de ces modalités ?

1 Oui 2 Non

SAT 
VIII Travail à l'étranger (hors CSN)

33. Quand vous avez quitté la France pour la $1^{\text {re }}$ fois, quelles étaient vos motivations ?

(Choix multiples possibles)

Róle déterminant Rôle accessoire Aucun rôle

MOTET

1 Liens familiaux, personnels

1 ............... 2 …......... 3

2 Perfectionner la langue

3 Déroulement de carrière, demande de l'employeur

4 Vous n'avez pas trouvé de travail en France

5 Création d'entreprise plus facile

6 Après un stage durant vos études.....

7 Après un séjour en coopération (VSN, CSN)

8 Poursuite d'étude ou post doc

9 Niveau de rémunération plus élevé

10 Recherche de dépaysement, autre culture

11 Recherche d'autonomie dans le travail

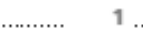

....

…........... 2 …........ 3

2

1.............. 2 …........ 3

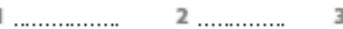

1 ............... 2 ............ 3

2 …….................

1 ............... 2 …........ 3

$1 \ldots \ldots \ldots \ldots \ldots . . . . \quad 2$............. 3

1 ............... 2 2 ............ 3

1.............. 2 …........

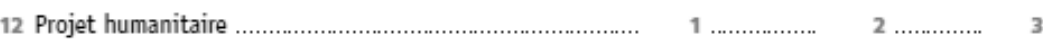

34. Quel a été le premier pays étranger où vous avez travaillé (indiquez le code postal international) : L1 L TETA

35. S'agissait-il aussi de votre premier emploi ? 1 0ui $\quad 2$ Non

36. Depuis que vous êtes ingénieur, combien de mois avez-vous travaillé à l'étranger ? Lــ LTR

37. Le cas échéant, votre conjoint(e) travaille-t-il (elle) à l'étranger ? 1 0ui $\quad 2$ Non CIET

Si vous travailliez à l'étranger au 31-12-2000 (hors CSN) :

38. Quel était votre statut ?
1 Salarié du privé sous contrat local
5 Fonctionnaire local
2 Salarié du prive de droit français
6 Travailleur indépendant
3 Contrat de chantier ou CDD
7 Bénévole
4 Fonctionnaire international ou français
8 Autre:

TEIST

39. Depuis combien de mois travaillez-vous dans ce pays ? $ـ \perp$ mois

40. Combien de temps encore pensez-vous travailler à l'étranger ? ــ ـ ـ années (si vous ne savez pas, notez 99 )

Si vous résidez en France, faites-vous des déplacements à l'étranger ? 1 Oui 2 Non DPL.

42. Combien de semaines avez-vous passé hors de France en 2000 :

\section{Renseignements complémentaires}

43. Vivez-vous en couple? 1 0ui 2 Non

44. Votre conjoint(e) a-t-il (elle) une activité professionnelle ? $\quad 1$ 0ui 2 Non

COUP

45. Combien d'enfants vivent dans votre foyer?

CJAP

46. Lorsque vous avez commencé vos études d'ingénieur, quelle était la profession de vos parents ? père mere

1 Cadre ou profession intellectuelle supérieure

1 Cadre ou profession intellectuelle supérieure

2 Profession intermédiaire

(technicien, instituteur, contremaitre)

2 Profession intermédiaire (technicien, institutrice, infirmière)

3 Employé

3 Employée

4 Ouvrier

4 Ouvrière

5 Travailleur indépendant

5 Travailleuse indépendante

6 Autre (retraité...)

6 Autre (femme au foyer, retraitée...) 